University of Nebraska - Lincoln

DigitalCommons@University of Nebraska - Lincoln

Publications from USDA-ARS / UNL Faculty

U.S. Department of Agriculture: Agricultural

Research Service, Lincoln, Nebraska

2017

\title{
Atmospheric Environment Associated with Animal Flight
}

J.K. Westbrook

USDA, Agricultural Research Service, College Station, john.westbrook@ars.usda.gov

R.S. Eyster

USDA, Agricultural Research Service, College Station, ritchie.eyster@ars.usda.gov

Follow this and additional works at: https://digitalcommons.unl.edu/usdaarsfacpub

Westbrook, J.K. and Eyster, R.S., "Atmospheric Environment Associated with Animal Flight" (2017). Publications from USDA-ARS / UNL Faculty. 2285.

https://digitalcommons.unl.edu/usdaarsfacpub/2285

This Article is brought to you for free and open access by the U.S. Department of Agriculture: Agricultural Research Service, Lincoln, Nebraska at DigitalCommons@University of Nebraska - Lincoln. It has been accepted for inclusion in Publications from USDA-ARS / UNL Faculty by an authorized administrator of DigitalCommons@University of Nebraska - Lincoln. 


\title{
Atmospheric Environment Associated with Animal Flight
}

\author{
J.K. Westbrook and R.S. Eyster
}

\begin{abstract}
The atmospheric environment can assist or restrict flight of animals (insects, birds, and bats), influencing their ability to extend their population range and find new habitats for food, mating, and shelter (Pedgley, Windborne pests and diseases: meteorology of airborne organisms. Ellis Horwood, 1982; Drake and Gatehouse, Insect migration: tracking resources through space and time. Cambridge University Press, 1995; Isard and Gage, Flow of life in the atmosphere: an airscape approach to understanding invasive organisms. Michigan State University Press, 2001; Drake and Reynolds, Radar entomology: observing insect flight and migration. CABI, 2012). Flight initiation may be influenced by air temperature, wind speed, wind direction, barometric pressure change, or other atmospheric variables and may require substantial convective lift for small invertebrates such as wingless insects and spiders. Flight displacement distance and direction largely depends on prevailing wind speed and wind direction at respective flight altitudes, although flying animals can add to their displacement speed and can alter their displacement direction by heading at an angle relative to the wind direction (Wolf et al., Southwestern Entomol Suppl 18:45-61, 1995), including upwind flight. While flying, animals may engage in predatory behaviors and conversely may be preyed upon. Long-distance flight of flying animals may be abruptly terminated by mid-latitude fronts, gust fronts, and precipitation. Ultimately, movement of animal populations in the atmosphere ranges across spatial and temporal scales spanning the microscale to macroscale and is vulnerable to changes in short-term weather and long-term climate patterns.
\end{abstract}

J.K. Westbrook $(\bowtie) \cdot$ R.S. Eyster

USDA, Agricultural Research Service, College Station, TX, USA

e-mail: john.westbrook@ars.usda.gov; ritchie.eyster@ars.usda.gov

(C) Springer International Publishing AG, part of Springer Nature 2017 


\section{Scales of Atmospheric Structure and Motion}

Animal flight is fundamentally a process that crosses vast spatial and temporal scales. This chapter examines the atmospheric properties, in time and space, that influence how diverse and numerous animal species engage in flight or wind-borne transport (Westbrook and Isard 1999). We discuss various scales of atmospheric structure and motion to describe atmospheric processes that lead to the distribution and displacement of flying animals. The definition of aeroecological boundary layers is based not only on the atmospheric environment but constrained to the spatial and temporal extent in which species of interest occupy that environment (Westbrook 2008). Aeroecological interest in particular species, or particular life activities, will dictate relevant atmospheric scales. We stress that flying animals do not readily fit into an aeroecologically scaled "box" but rather fit within an aeroecological continuum. Application of an aeroecological continuum is clearly needed as animals ascend into the atmosphere, and for directed flights that extend either continuously or discontinuously. We discuss atmospheric structure and motions that are relevant to all animal species that fly through the atmosphere within a range of spatial and temporal scales, by describing the atmospheric environment cascading from the macroscale to the mesoscale and microscale.

Several key terms must be defined to describe the atmospheric environment as it relates to animal flight. First, the scales of motion range from microscale $(\leq 2 \mathrm{~km})$, to mesoscale ( 2 to several hundred $\mathrm{km}$ ), and to macroscale $(\geq 1000 \mathrm{~km})$. An individual animal could conceivably engage in flight that is influenced by the entire scale of atmospheric motions for example by initiating flight in response to turbulent gusts; flying continuously in a low-level jet (i.e., maximum in the vertical profile of wind speed) for several hundred kilometers; and continuing on successive flights over a distance of more than $1000 \mathrm{~km}$ (and affected by synoptic weather features such as frontal systems). All of these atmospheric motions occur in the troposphere, which is the part of the atmosphere where most weather occurs and extends from the surface to $10-20 \mathrm{~km}$ above ground level. The lowest part of the troposphere is the atmospheric boundary layer which is of variable depth, ranging from tens of meters to several $\mathrm{km}$ depending on the height of low-altitude temperature inversions (i.e., air temperature increasing with height) which limit the vertical extent of convection. Animals may fly within or above the atmospheric boundary layer, depending on the species, activity phase, and atmospheric conditions.

Historically, the science of understanding animal flight in the atmosphere has been termed aerobiology, or a niche within the broader realm of biometeorology. While biometeorology describes atmospheric effects on fauna and flora, the subject has largely focused on atmospheric impacts while the fauna and flora are on the ground. Aerobiology focuses on the presence of airborne biota, but has principally addressed inanimate biota, including pollen, spores, and bacteria, rather than flying animals. However, Kunz et al. (2008) either coined or made popular the field of aeroecology to emphasize the behavior and activity of flying animals, including aerial interactions between taxa and species. 
Table 2.1 Typical reflection of sunlight by various surfaces

\begin{tabular}{l|l}
\hline Surface & Albedo (\%) \\
\hline New snow & 90 \\
\hline Old snow & 50 \\
\hline Average cloud cover & 50 \\
\hline Light sand & 40 \\
\hline Light soil & 25 \\
\hline Concrete & 25 \\
\hline Green crops & 20 \\
\hline Green forests & 15 \\
\hline Dark soil & 10 \\
\hline Asphalt & 8 \\
\hline Water & 8 \\
\hline
\end{tabular}

\section{$2 \quad$ Atmospheric Thermodynamics and Kinematics}

Atmospheric thermodynamics describes the conversion of heat into work energy and consequently from potential energy to kinetic energy (expressed as wind) in the atmosphere. The sun is the heat source that modifies the atmospheric structure of temperature, humidity, and pressure and generates atmospheric motions and circulations. Seasonal changes in the amount of insolation at the top of the atmosphere are caused by the elliptical solar orbit (and changing distances between the earth and sun), and local variations are due to solar angle (associated with location latitude). Further reductions in insolation at the earth surface are due to clouds and atmospheric contaminants that reflect or reemit incident solar radiation primarily back to space. The heterogeneous earth surface comprises a wide array of soil types, vegetation types, and water bodies, each of which has a specific reflectance characteristic known as albedo (percentage of reflected incident solar radiation across all wavelengths of energy). The albedo of a particular unit of land surface will change when the surface is wet or covered with ice or snow; vegetation cover increases; vegetation grows or senesces; and water bodies freeze (Table 2.1). Differential absorption of insolation and subsequent heating of individual units of land surface leads to surface gradients of temperature. In turn, horizontal temperature gradients cause barometric pressure gradients that shape global, regional, and local atmospheric circulations.

\section{Macroscale}

The atmosphere drives many of the movements of biota around the world. These movements can be considered as local, regional, continental, and global. This section will cover the continental and global scale atmospheric structure and air flow. To better understand the role of the atmosphere in driving actions in the aerosphere, we will begin at the largest scales and drive down to the small scale. 


\subsection{Global Circulation}

We begin by looking at the atmosphere on a global scale (Fig. 2.1). There are largescale circulations such as the Hadley Cell in the subtropics, the Ferrel or Mid-latitude Cell, and the Polar Cell. All of these are driven by differences in the heat from incident solar radiation at the surface and aloft. At the Equator, the atmospheric circulation is marked by the Inter-Tropical Convergence Zone (ITCZ). This area of the global circulation is known as the Doldrums where there is very little wind. Here the warm and humid air rises resulting in storms which transport warm air to higher levels of the atmosphere. The flow then moves poleward as the air cools and begins to sink. This sinking air comes back to the earth surface in the regions of the world's deserts. Figure 2.2 illustrates a cross-sectional view of the circulation associated with each of the cells. In the Northern and Southern Hemispheres, the Ferrel Cell is the area in which surface pressure systems are active. The Ferrel Cell is the dividing circulation between the cold polar air and the

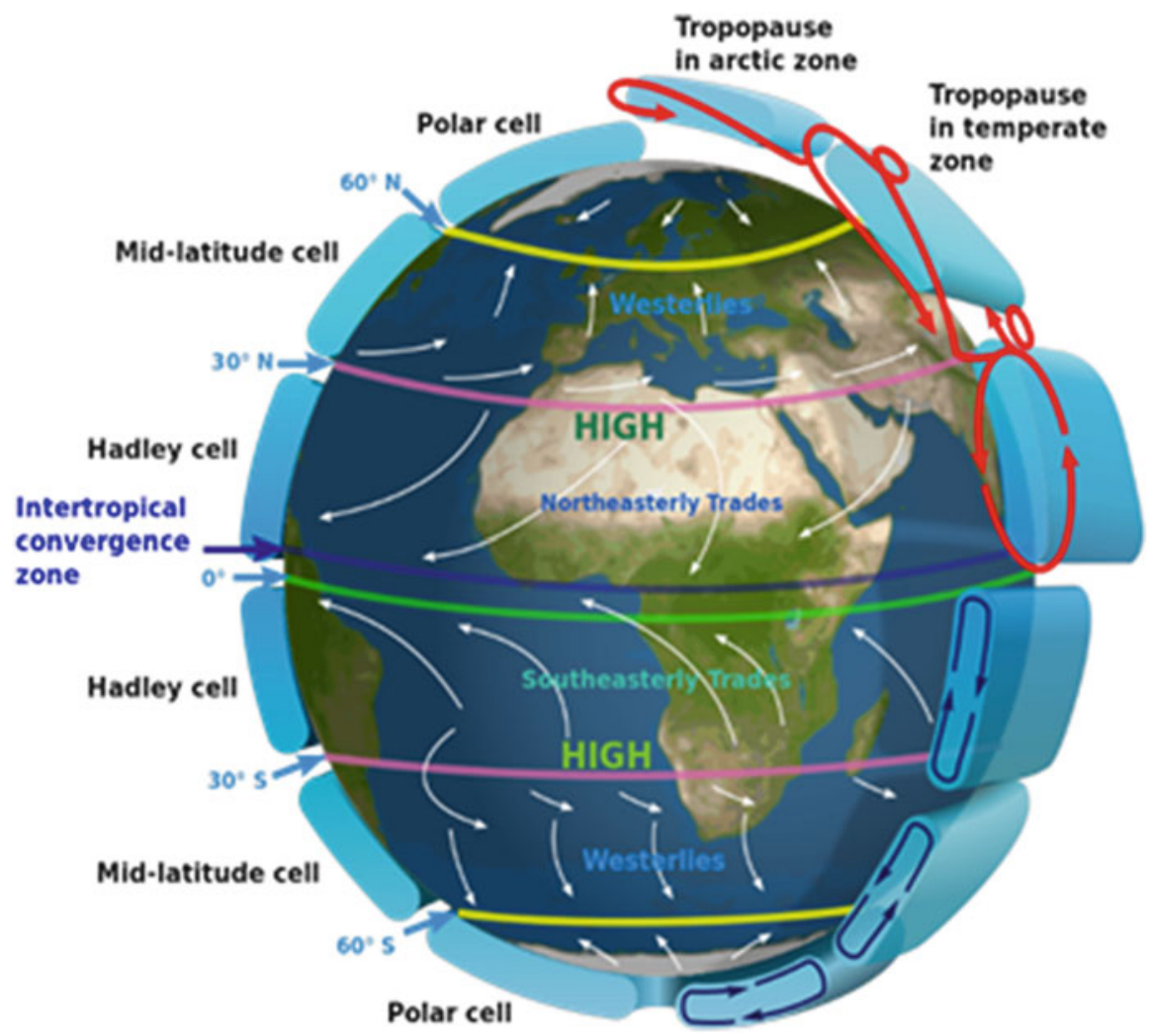

Fig. 2.1 Global Circulation with the three NS circulations: (1) Hadley, (2) Ferrel, and (3) Polar. The ITCZ, Easterly Trade Winds, Mid-Latitude Westerlies, and Polar Easterlies are indicated. http://commons.wikimedia.org/wiki/File:Earth_Global_Circulation_-_en.svg 


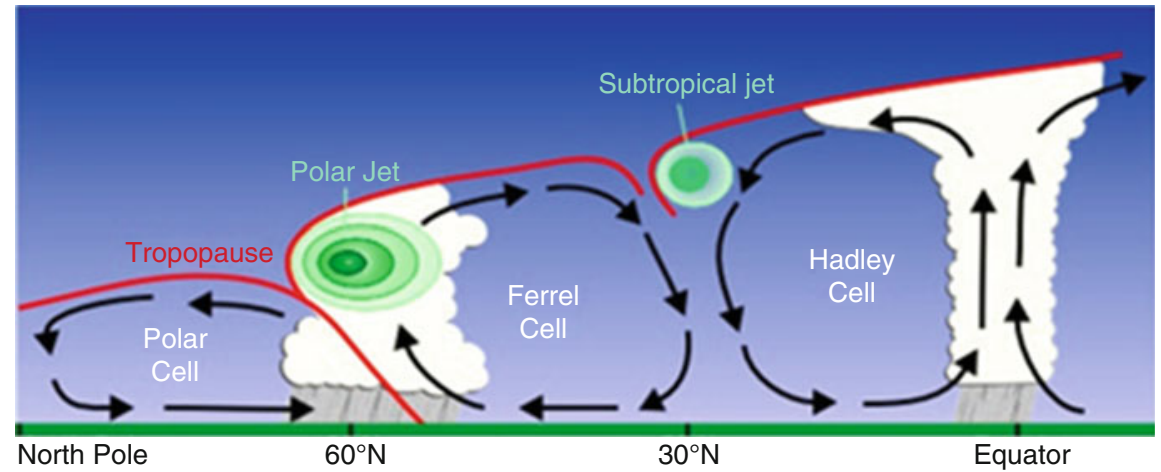

Fig. 2.2 Cross-sectional view of the Hadley, Ferrel, and Polar circulations with the tropopause, polar jet stream, and subtropical jet stream locations indicated. http://www.srh.noaa.gov/jetstream/ global/jet.htm

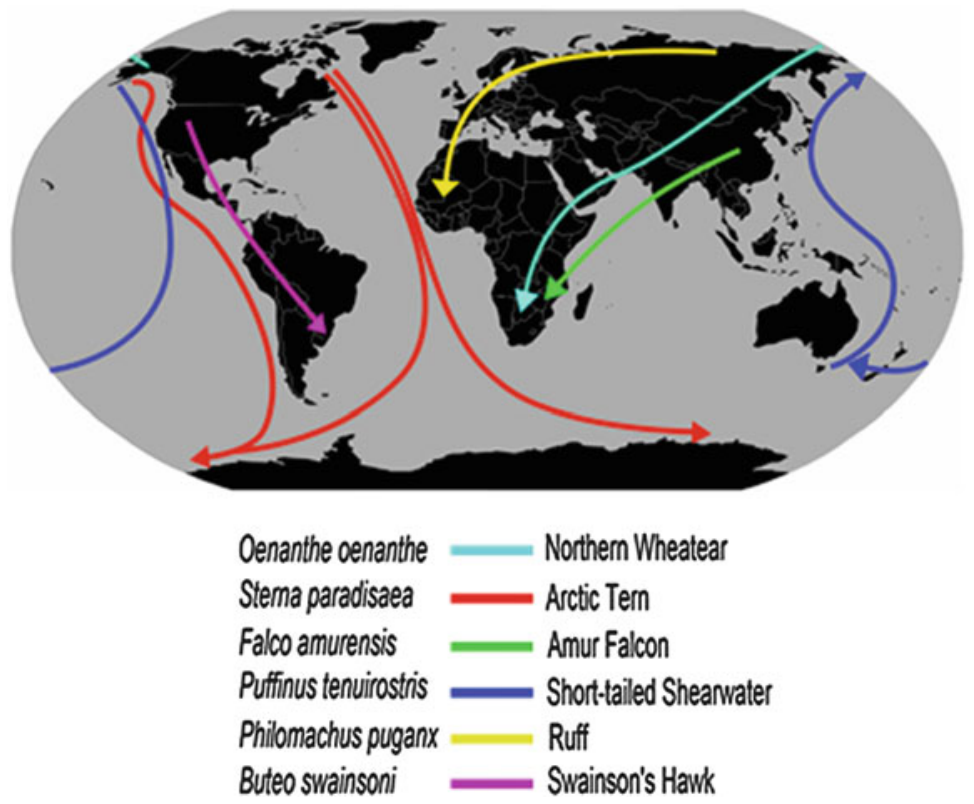

Fig. 2.3 Global bird migration routes (Shyamal, L. 2008. Own work: Migration routes of birds based on Newton, I. The Migration Ecology of Birds. Academic Press)

warm tropical air. The Ferrel Cell is bound at the tropopause by the subtropical and polar jet streams. Convection occurs at the equator and at the location of the polar jet. The subtropical jet is located over the sinking air at $30^{\circ} \mathrm{N}$ and $30^{\circ} \mathrm{S}$. The jet stream locations vary season to season. At the poles, the air sinks resulting in cold high pressure. There are several bird species which migrate between hemispheres. Shyamal adapted a figure (Fig. 2.3) showing macroscale migration routes of birds. 
The macroscale circulation cells may be a factor in these long-distance hemispheric migrations.

There are other circulations which transport energy from East to West. The first is the Walker Circulation which is associated with the El Niño/Southern Oscillation (ENSO) circulation in the Pacific Ocean. The Walker Circulation is East to West at the surface and West to East aloft. Figures 2.4 and 2.5 illustrate how the strength of the Walker circulation determines the strength of the Easterly Trade Winds and the depth of the thermocline in the Eastern Pacific near the coasts of Central and South America. El Niño conditions are a result of weak trade winds which suppress the thermocline and result in above normal sea surface temperatures. La Niña conditions are a result of strong trade winds which cause upwelling and below normal sea surface temperatures. The Madden-Julian Oscillation (MJO) is an eastward moving circulation or wave along the ITCZ (Madden and Julian 1971, 1972). The MJO is most commonly associated with increased convection in the Indian and Pacific Oceans. The MJO can also be seen in the Atlantic Ocean and over Africa (Madden and Julian 1971, 1972). This circulation when in phase with westward moving (easterly) waves can enhance convection and result in the development of strong tropical systems in the subtropical areas of the oceans. These tropical systems have been known to transport birds, and beneficial and pest insects (Westbrook 2008).

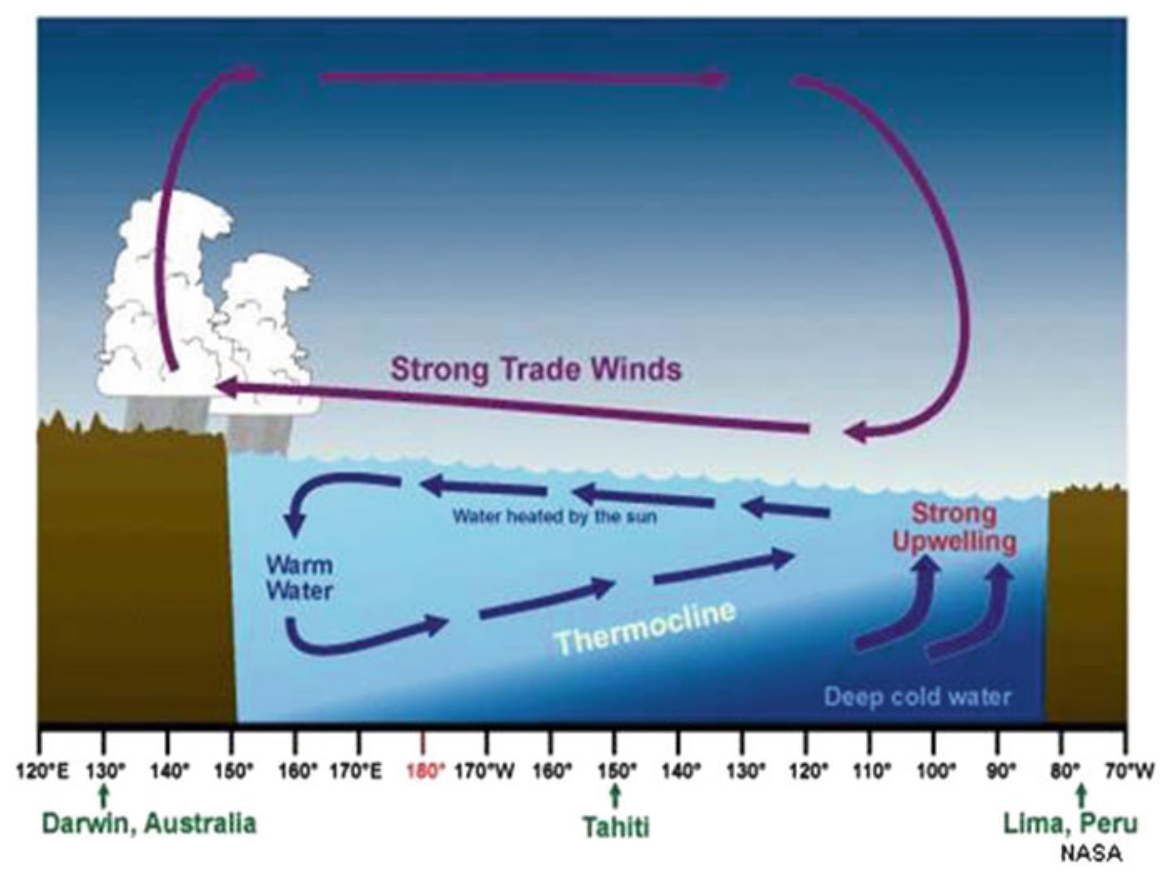

Fig. 2.4 Walker circulation associated with La Niña. http://oceanservice.noaa.gov/yos/resource/ JetStream/tropics/enso_patterns.htm 


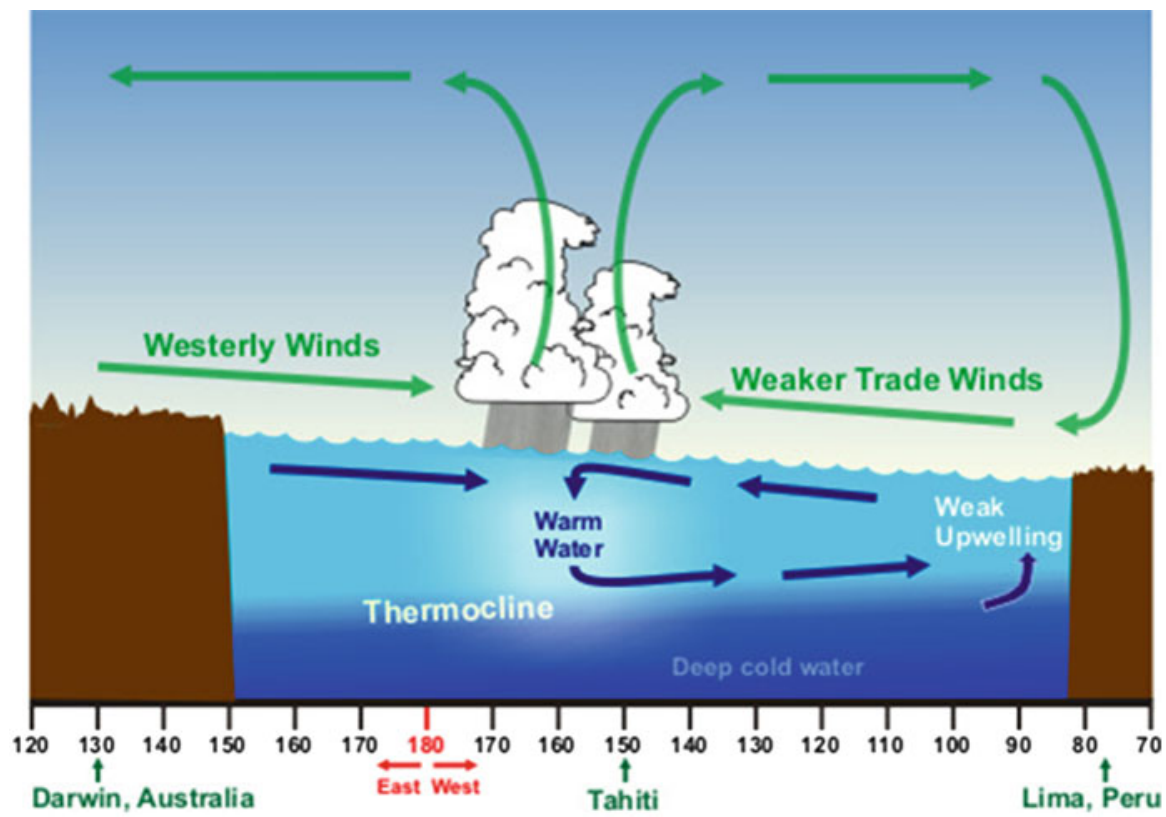

Fig. 2.5 Walker circulation associated with El Niño. http://oceanservice.noaa.gov/yos/resource/ JetStream/tropics/enso_patterns.htm

\subsubsection{The Coriolis Effect}

The general global flow comprises the Easterly Trade Winds in the subtropical latitudes, Westerlies in the mid-latitudes, and polar Easterlies in the Arctic and Antarctic regions. These wind patterns result from the rotation of the earth and the direction of air movement. Figure 2.6 illustrates the Coriolis Effect on meridional flow (poleward) and zonal flow (west to east). When air flows poleward, the apparent motion is eastward resulting from the Coriolis force. When the air flow is toward the equator, the apparent motion is westward. The Coriolis force is greatest at the poles and near zero at the equator. The global wind patterns transport warm and cold air across the globe. The formation and movement of large-scale atmospheric waves can be observed through cloud motions. These large-scale or Rossby waves are the general drivers of mid-latitude weather systems. In the tropics and subtropics, easterlies drive the movement of tropical systems such as hurricanes, typhoons, and cyclones over the world's oceans.

\subsection{Tropical and Subtropical Systems}

In the tropical and subtropical regions of the earth, summer and fall brings the development of tropical storms. These storms are called hurricanes, cyclones, or 


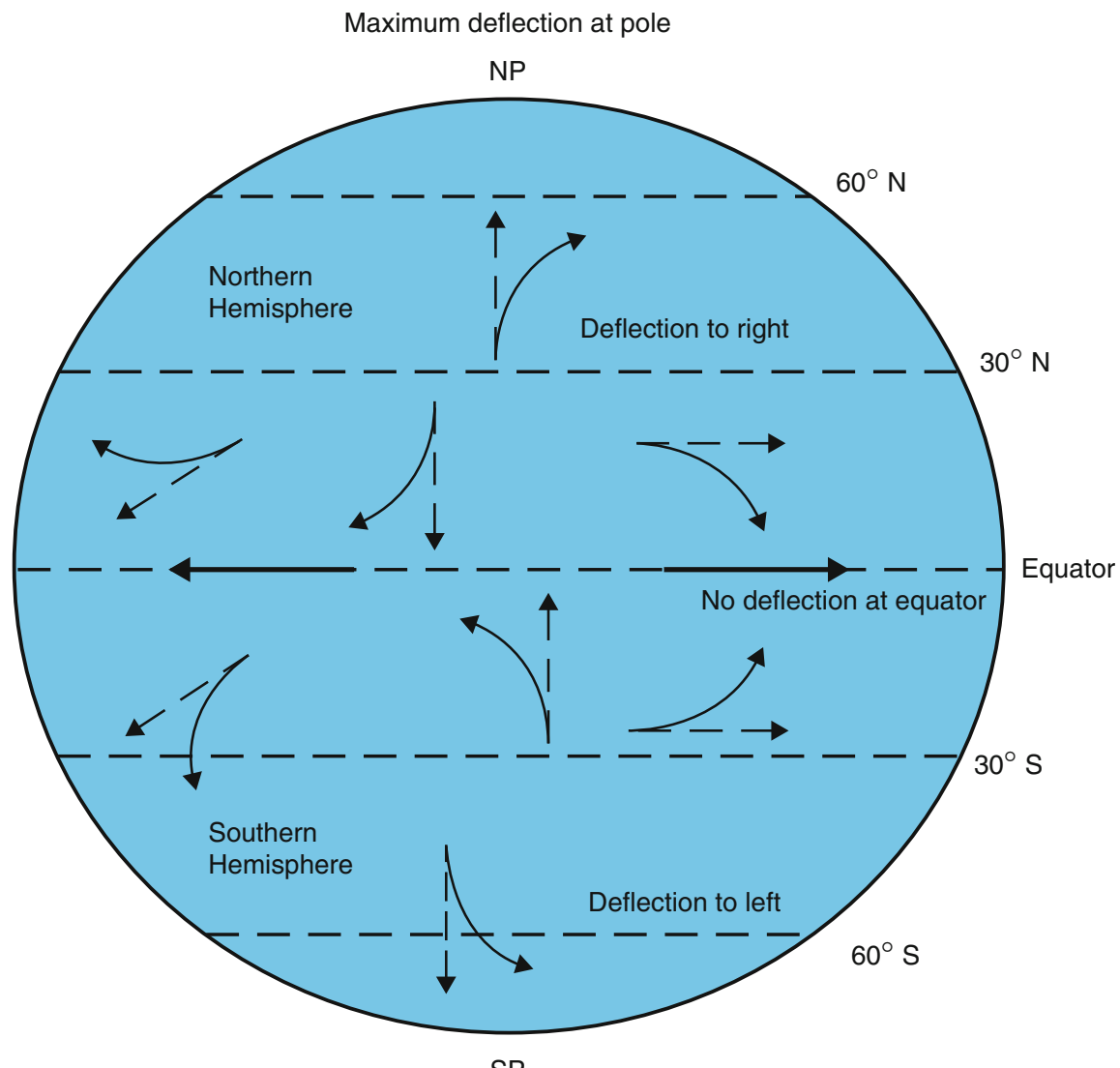

SP

Maximum deflection at pole

Fig. 2.6 Coriolis Effect on wind flows in both the Northern and Southern hemispheres. Airflow is deflected to the right in the northern hemisphere and to the left in the southern hemisphere. Image/ photo courtesy of the National Snow and Ice Data Center, University of Colorado, Boulder

typhoons depending in which part of the world they develop. The time of year in which these storms occur may result in enhanced movement by the circulation in and around the storm. Figure 2.7 is a case study of a tropical storm which moved through South and West Texas over a 5-day period in August. The Southern Rolling Plains eradication zone (red counties on Fig. 2.7) did not have any boll weevils present for several years before this event. After Tropical Storm Erin moved through Texas, boll weevils were found across the southern part of the Southern Rolling Plains eradication zone (Kim et al. 2010). The middle of August is the time of cotton harvest in the South Texas/Winter Garden eradication zone (yellow counties on Fig. 2.6) as well as in the Southern Blacklands eradication zone (green counties on Fig. 2.6). Over a 3-day period (August 17-19), backward atmospheric trajectories calculated using the HYSPLIT model (Draxler and Hess 1998) identified probable boll weevil origins in the South Texas/Winter Garden 


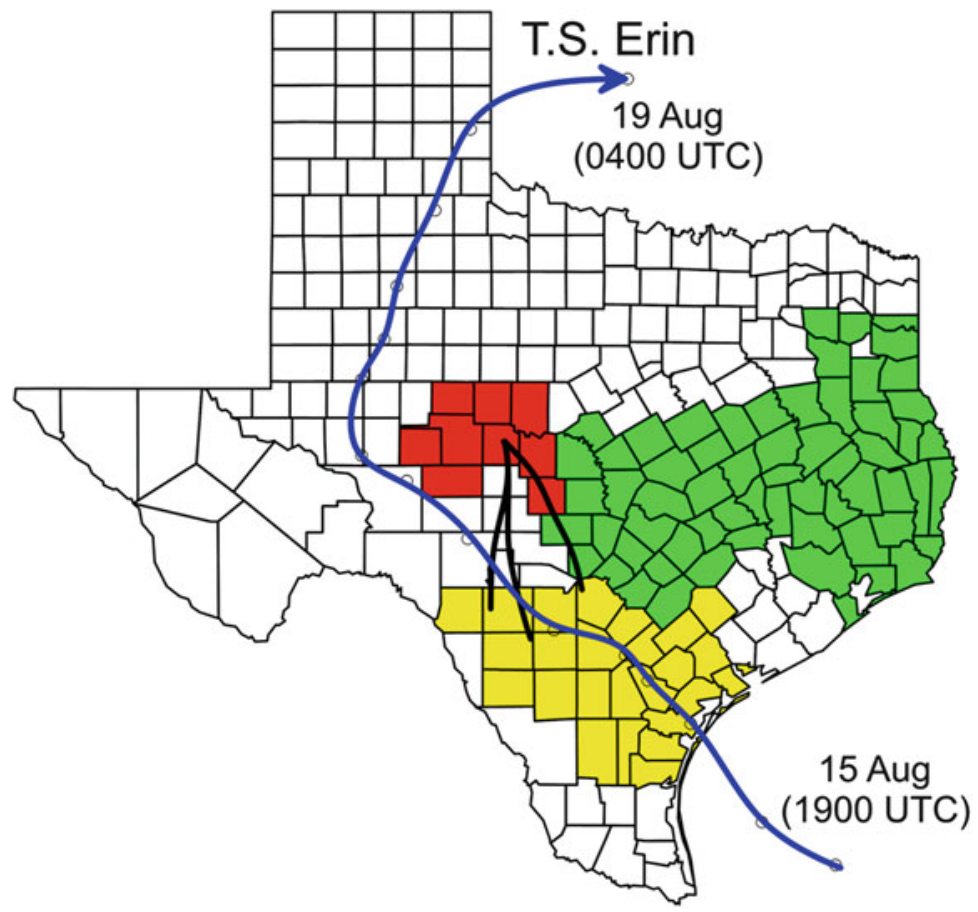

Fig. 2.7 Track of the center of circulation of Tropical Storm Erin (blue line) and backward atmospheric trajectories (black lines) from the location of a boll weevil reinfestation in the Southern Rolling Plains eradication zone (red counties). Boll weevil populations had not yet been eradicated in the Southern Blacklands eradication zone (green counties) and the South Texas/ Winter Garden eradication zone (yellow counties). Figure reprinted courtesy of the International Journal of Biometeorology

eradication zone. Analysis of DNA and pollen taken from boll weevils captured in the Southern Rolling Plains eradication zone strongly indicated that the boll weevils arrived from the Winter Garden district (Kim et al. 2010). This evidence suggests that tropical storms can move biota from tropical and subtropical regions of the world to temperate regions, which can result in infestations or reinfestations of pest insects.

\subsection{Monsoons}

In certain parts of the world such as India and southeast Asia, there is the seasonal monsoon flow. During the wet phase of the monsoon, air flow is from southeast though southwest directions (Pidwirny 2006; Dowling 2014). This air flow can be a mechanism to transport biota from tropical regions to agricultural regions northwest through northeast (Figs. 2.8 and 2.9). During the dry phase of the monsoon, air flow is from northeast through northwest (Figs. 2.8 and 2.9). This flow can act to help transport biota back to agricultural areas and warmer areas for overwintering. These 

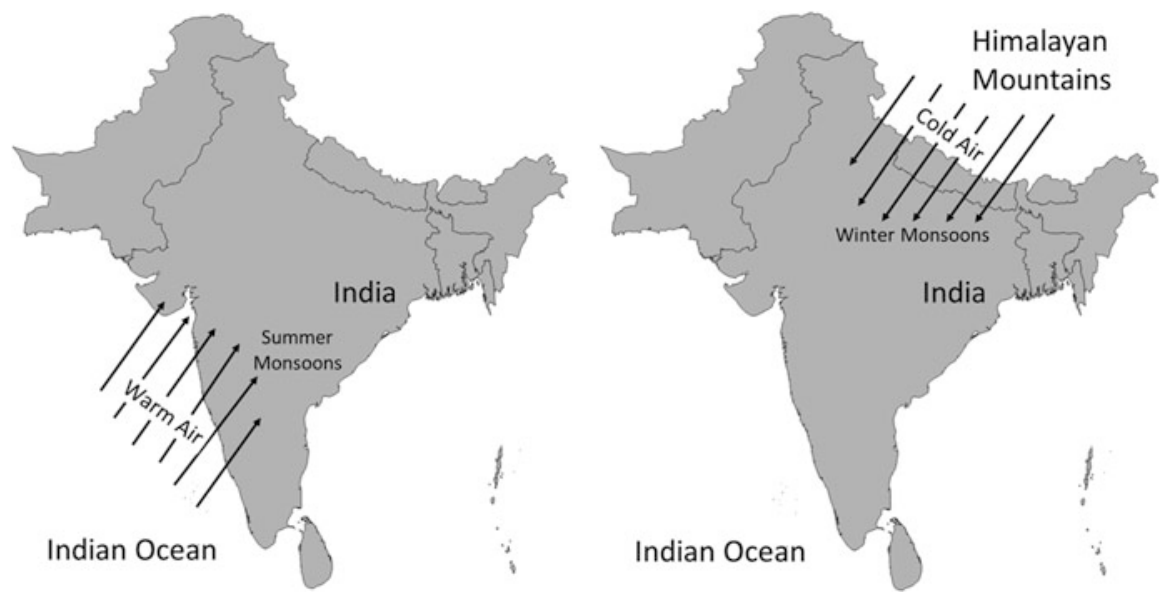

Fig. 2.8 Mean wind direction for India monsoons in the Northern Hemisphere summer and winter
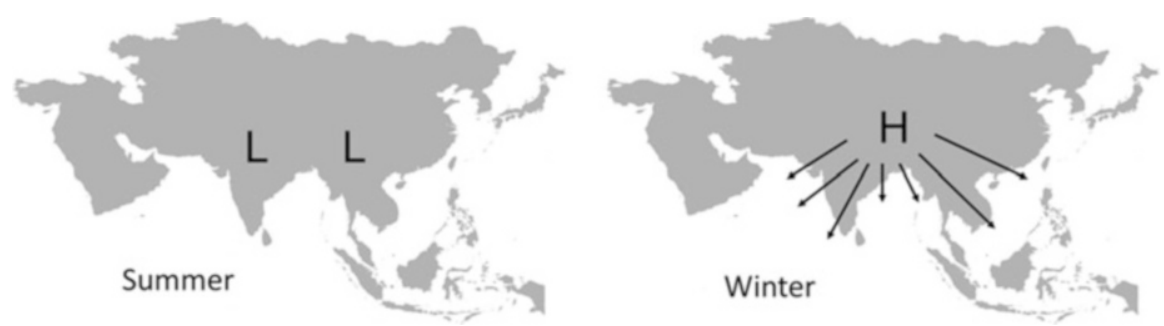

Fig. 2.9 Monsoon wind flow across India and Southeast Asia in the Northern Hemisphere summer and winter

monsoonal flows occur in other regions as well and signal the start of growth of food sources. An example of a frequent summertime atmospheric pressure system in the USA is the Four Corners Low, which is centered over the four-state area (Utah, Arizona, Colorado, and New Mexico) in the southwestern USA (Fig. 2.10). The Four Corners Low creates an atmospheric pattern that entrains subtropical moisture and creates monsoon-type conditions in the USA desert southwest. There are other areas throughout the world that experience similar monsoonal flows. Most of these flows are around quasi-stationary subtropical high-pressure regions at and around $30^{\circ} \mathrm{N}$ and $30^{\circ} \mathrm{S}$ latitude (Figs. 2.11, 2.12, and 2.13). These areas include Australia, South America, and Africa. The monsoonal flow in these areas is driven by the location of the ITCZ. The Southwest USA monsoon is driven by the low surface pressure as a result of desert high heat. The ITCZ remains well south of the continental USA. 


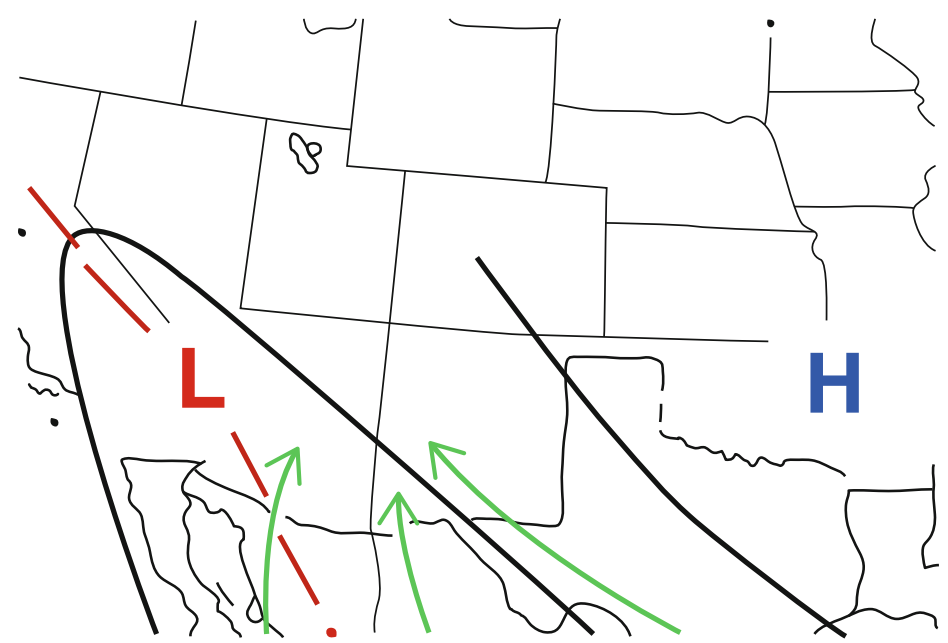

Fig. 2.10 Southwest USA summer monsoon air flow. http://www.srh.noaa.gov/elp/swww/v8n1/ monsoonmapb.jpg
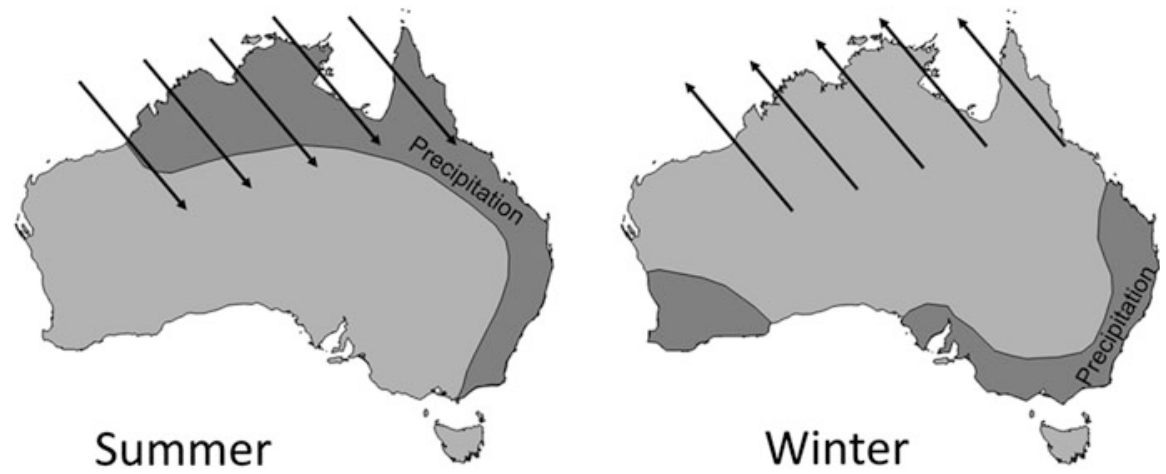

Fig. 2.11 Australian monsoon air flow in the Southern Hemisphere summer and winter

\subsection{Quasi-stationary Mid-Latitude Pressure Systems}

Regions of quasi-stationary or persistent atmospheric pressure systems are often named to identify atmospheric features that influence mesoscale and macroscale flow (Figs. 2.14 and 2.15). An example of a quasi-stationary atmospheric pressure system is the Bermuda High, which generally resides over Bermuda Island near the southeastern coast of the USA. This feature is the western part of the Azores High. The Bermuda High drives southerly flow over the southern USA, but often retrogresses and displaces the southerly flow westward. This extension of the Bermuda High guides tropical storms into and through the Gulf of Mexico and guides surface low-pressure systems north and away from the southeastern USA. 

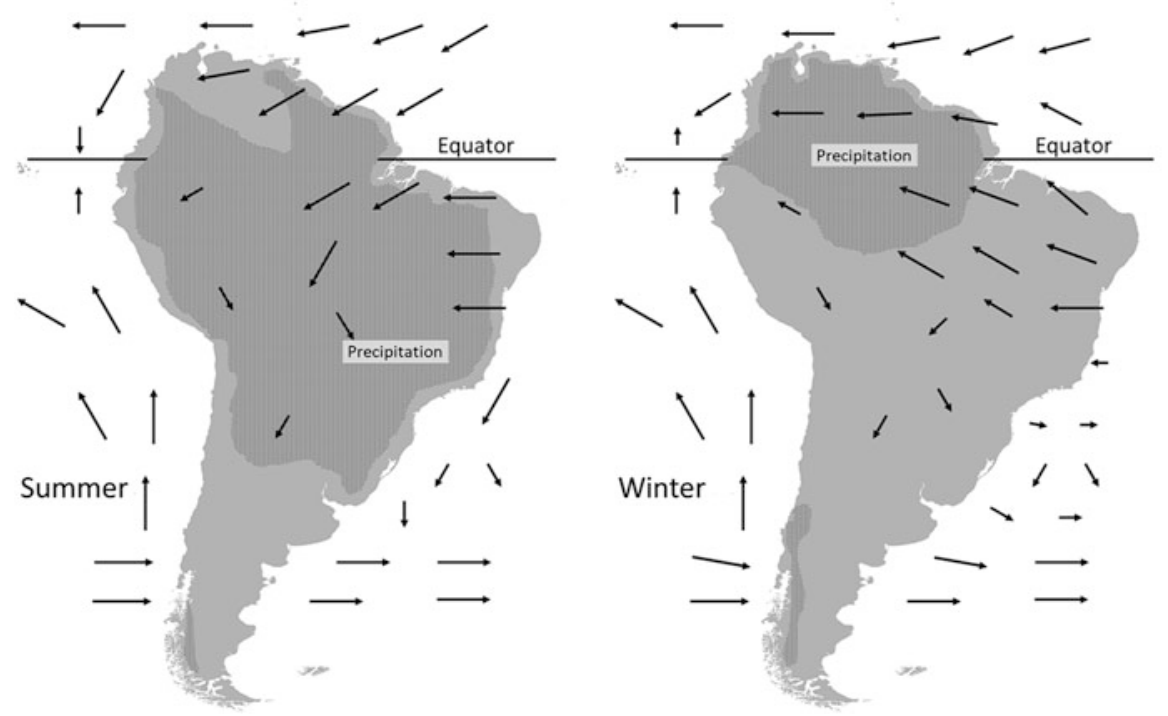

Fig. 2.12 South America monsoon air flow in the Southern Hemisphere summer and winter
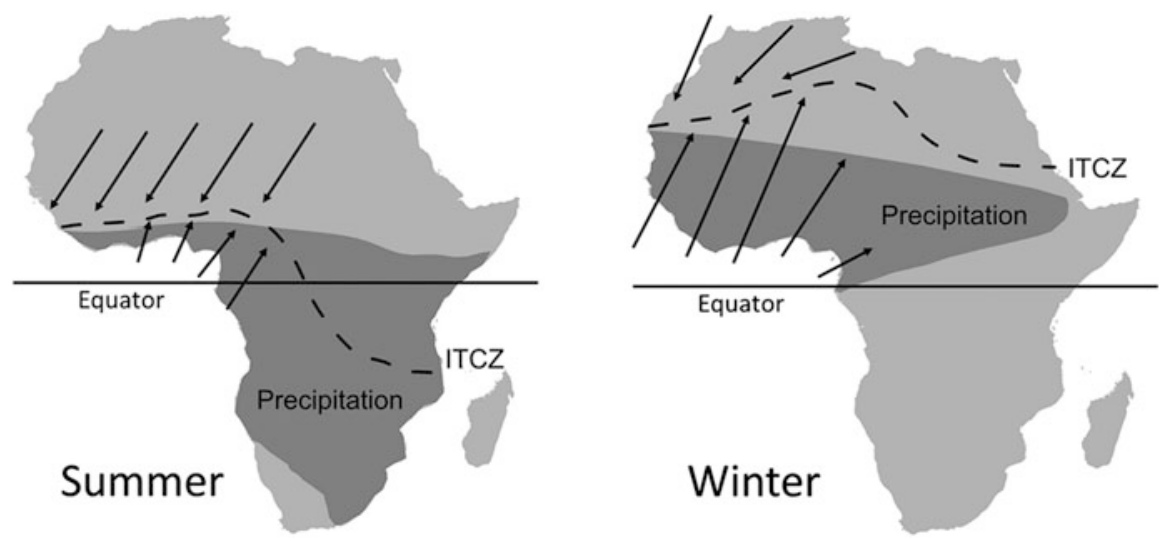

Fig. 2.13 Africa monsoon air flow in the Southern Hemisphere summer and winter

Each continent has air flows that are conducive to migration and dispersal of biota. Australia and parts of South America and southern Africa are the only large land areas in the Southern Hemisphere that support large-scale agricultural production. Figures 2.14 and 2.15 show summer and winter macroscale flows across South America, southern Africa, and Australia. High pressure is dominant on the western side of South America and southern Africa in January, resulting in deserts along the coastal areas. July has a similar pressure pattern with high pressure over the Indian Ocean moving west to Southeast Africa and high pressure developing over 


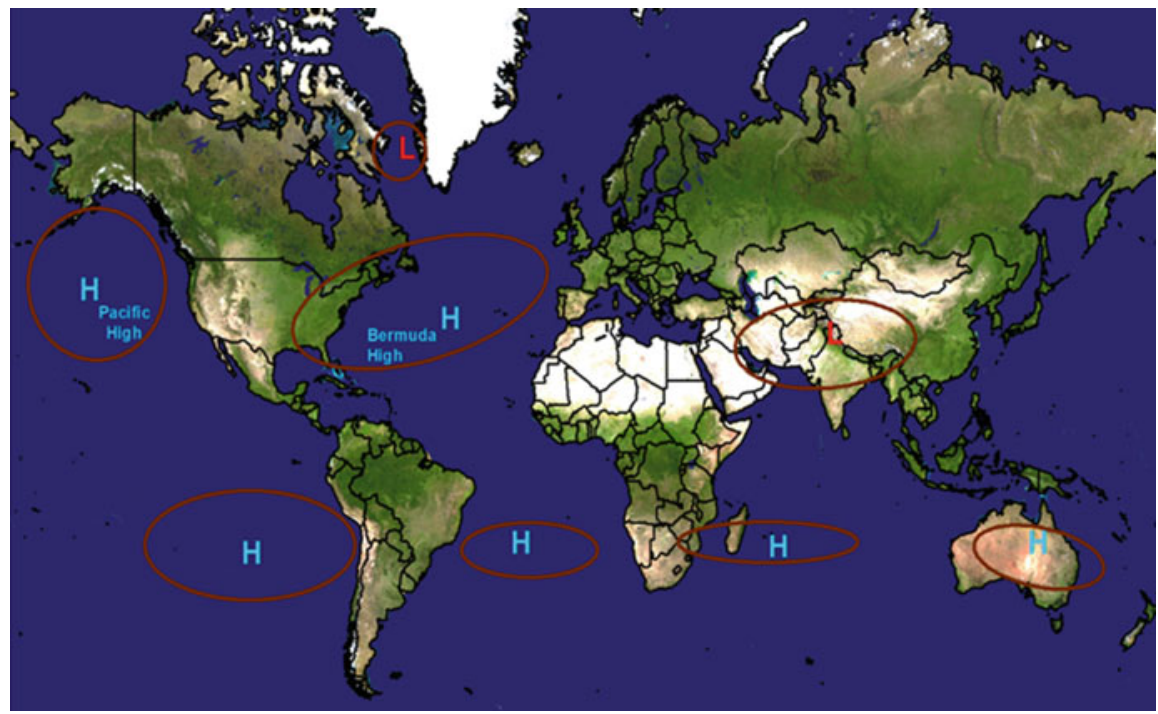

Fig. 2.14 Quasi-stationary atmospheric pressure systems during summer in the Northern Hemisphere. Ellipses indicate the extent of high-pressure $(\mathrm{H})$ and low-pressure $(\mathrm{L})$ systems. The Pacific High and Bermuda High are labeled. Basemap from ESRI Inc

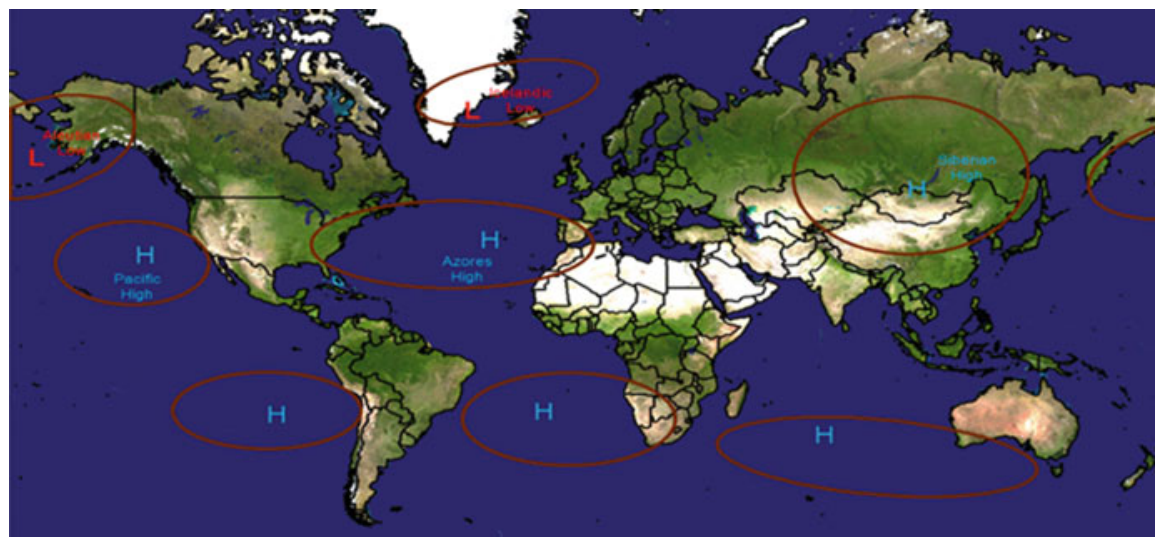

Fig. 2.15 Quasi-stationary atmospheric pressure systems during winter in the Northern Hemisphere. Ellipses indicate extent of high-pressure and low-pressure (L) systems. The Aleutian Low, Icelandic Low, Pacific High, and Azores High are labeled. Basemap from ESRI Inc

Australia (Fig. 2.14). The high-pressure area to the west of South America remains in the same general vicinity (Haltiner and Martin 1957). The locations of these high-pressure systems are quasi-stationary throughout the year. Similar atmospheric flows occur in the Southern Hemisphere as in the Northern Hemisphere and result in similar seasonal migration and dispersal of biota. 


\subsubsection{Flow to and from Desert Regions}

There are other large-scale circulations that are able to move biota from tropical and subtropical latitudes to temperate areas. Some of these flows are around the world deserts. Deserts are associated with strong high pressure aloft and strong low-pressure systems at the surface due to extreme heat. The resulting air flow moves biota from the periphery of the surface low pressure toward the north on the east side and toward the south on the west side. These flows have been associated with massive movements of biota from Africa to the Middle East and Europe. Figure 2.16 illustrates the major wind flows around the Mediterranean Sea for summer and winter. Strong winds can blow in from the Sahara Desert as well as from Europe toward northern Africa. These air flow patterns can be conducive to long-range dispersal of biota.

\subsection{Mid-Latitude Circulation}

The evolution of Rossby waves is governed by differential heating between the poles and equator (Fig. 2.17). The flow around the Polar Low begins as zonal flow or winds from west to east. As differential heating occurs, energy balance requires the movement of warm air toward cold air and cold air toward warm air. This results in the formation of atmospheric troughs and ridges (i.e., waves) in the mid-latitudes. The number of these atmospheric waves around the hemisphere governs the stability of the global circulation. The mean winter wavelength is $7025 \mathrm{~km}$, while the mean wavelength in summer is $4967 \mathrm{~km}$. If the wavelength is shorter than the

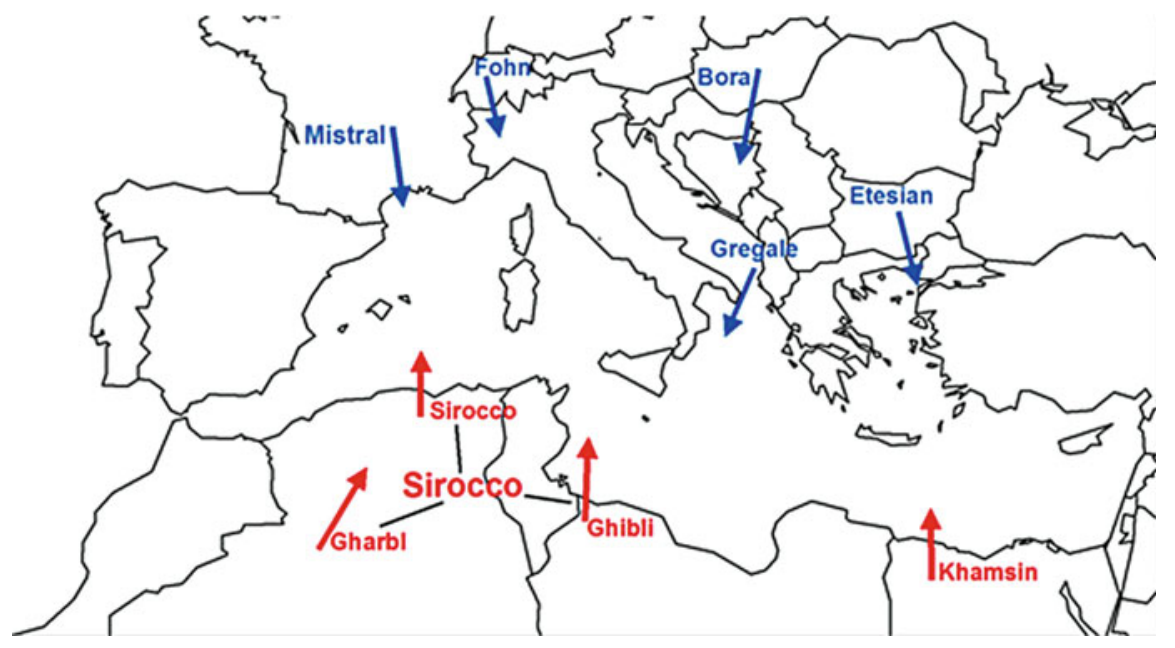

Fig. 2.16 Descriptive names for hot, dry winds (red) and cold winds (blue) in the Mediterranean region during the Northern Hemisphere summer and winter, respectively. Basemap From ESRI, Inc 
(a)

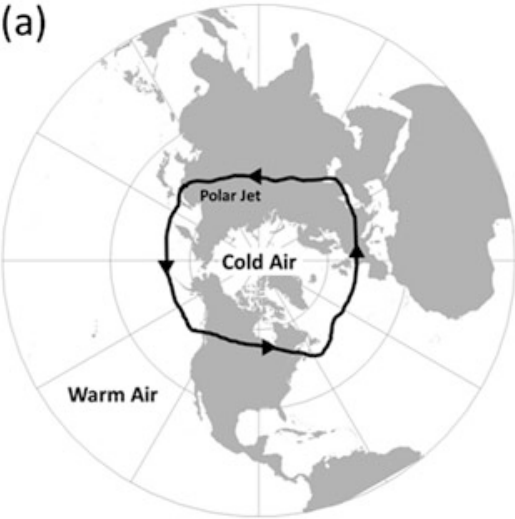

(c)

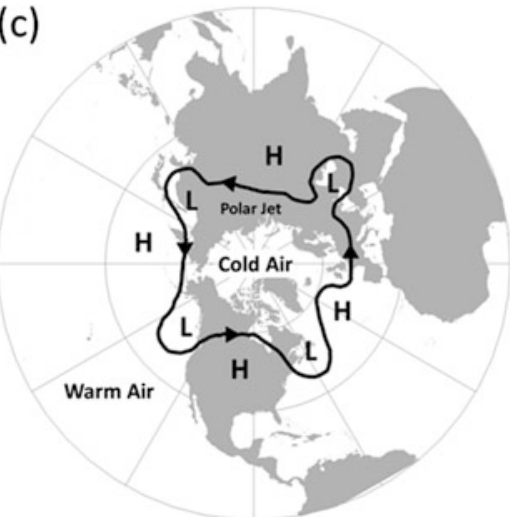

(b)

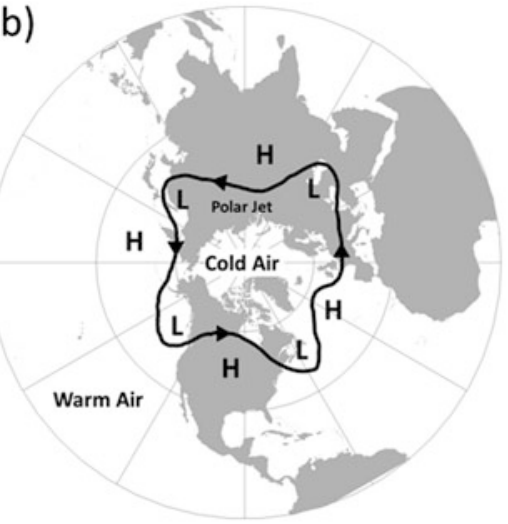

(d)

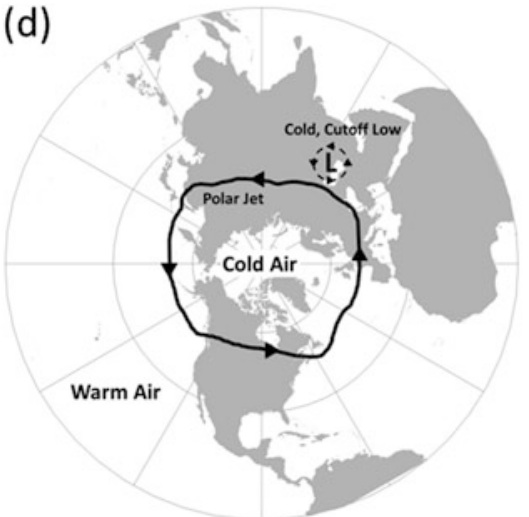

Fig. 2.17 Evolution of Rossby waves in the polar jet stream around the Northern Hemisphere polar vortex: (a) circulation relatively undisturbed; (b) incipient waves develop; (c) wave amplitude increases; and (d) circulation relatively undisturbed with new cutoff low-pressure cell

mean, the waves move eastward. If the wavelength is longer than the mean the waves move westward (Wallace and Hobbs 1977; (Haltiner and Martin 1957; Haltiner and Williams 1980). Superimposed on the Rossby waves are short waves. Short waves move rapidly downwind in the jet stream flow (Haltiner and Martin 1957). When the short wave and long wave are in phase, the overall wave becomes very high amplitude resulting in cold air moving far toward the equator and warm air moving far toward the poles. It is important to observe the hemispheric wave pattern to determine the potential for atmospheric wave amplification and subsequent changes in surface pressure and wind patterns that are conducive to migration of biota. 


\subsubsection{Mid-Latitude Blocking Patterns}

The mid-latitude wave train can develop into what are known as blocking patterns. There are several upper air wind flows known as blocking patterns. Blocking patterns are caused by large and strong high pressure at $500 \mathrm{mb}$ level (see Sect. 3.5.2). Some of these are the Cut-off Low (Fig. 2.18a), the Omega Block (Fig. 2.18b), the Rex Block (Fig. 2.18c), the Ring-of-Fire Block (Fig. 2.18d), and the Split-Flow Block (Fig. 2.18e) (Haby 2015). These blocking patterns can persist for 2-3 weeks and can develop in either hemisphere. Omega Blocks, Rex Blocks, and Split-Flow Blocks are most common in the late winter and spring. Cut-Off Low Blocks can occur at any time of year but are least common in the winter. The Ringof-Fire Block is a common summer blocking feature, usually appearing on the west side of quasi-stationary high-pressure ridges. This blocking pattern is common in the southeastern USA during the summer and is an expansion of the Azores/ Bermuda high to the west (Haby 2015). The Omega Block can break down to form either a Cut-Off Low, Split-Flow, or Rex Block. The Cut-Off Low and Omega Block can lead to sustained periods of flow conducive to animal migrations in the

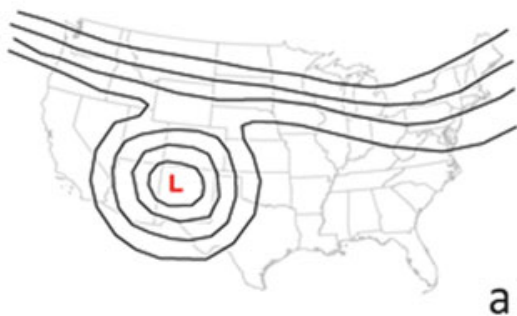

a

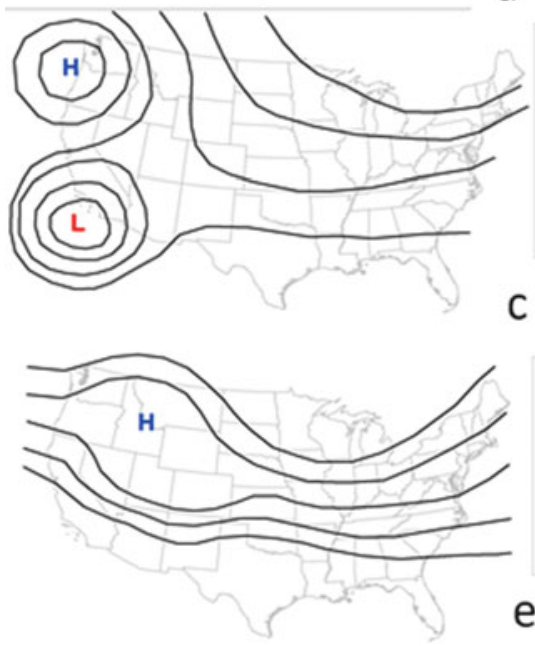

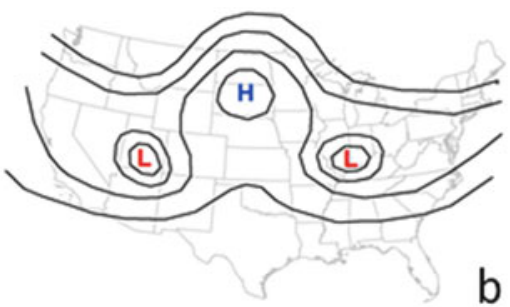

b

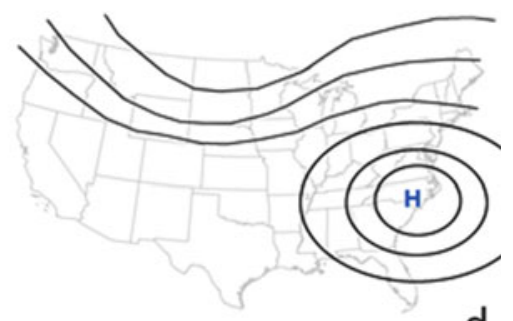

C

$\cdot \cdot$

H

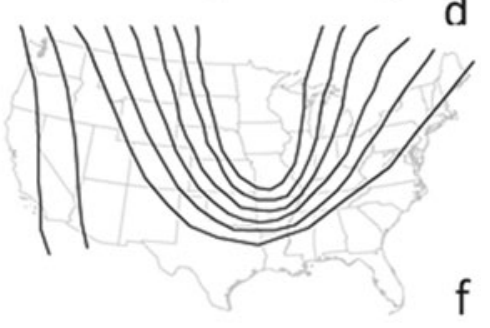

Fig. 2.18 Illustrations of atmospheric blocking patterns: (a) Cut-Off Low, (b) Omega Block, (c) Rex Block, (d) Ring-of-fire Block, (e) Split-Flow Block, and (f) El Niño blocking high pressure. Basemap from ESRI, Inc. Illustrations based on Haby (2015) 
atmosphere. Surface low pressure develops underneath the upper low resulting in surface flow from the south. If the block sets up over the Four Corners area of the USA, southerly flow will be over the Central and Southern Plains. Many birds and insects overwinter in southern and coastal areas of Texas, Louisiana, Mississippi, Alabama, Florida, and Mexico. Southerly winds bring ideal conditions for movement of biota to the north (Muller 1977). One example is the yearly migration of the monarch butterfly. Figure 2.19 illustrates the known flyways of the monarch butterfly from overwintering sites in Mexico, California, and Florida. The monarch butterfly flies north throughout the spring and summer, reaching its breeding grounds in four to five generations (MonarchWatch.org). In the fall, this final generation migrates back to overwintering sites. Another common blocking pattern is associated with El Niño conditions in the eastern Pacific Ocean. Figure 2.18f illustrates the strong ridge of high pressure that forms across the western USA and adjacent waters of the Pacific Ocean in association with El Niño conditions. These conditions can exist for several months and result in severe drought conditions in the western USA.

\subsubsection{Structure of Troughs and Ridges}

A trough of low pressure is visualized by the height of a constant pressure surface (Fig. 2.20). At the center of the trough, the height of the pressure surface is lower than at the outer extent of the trough. Conversely, the height of the pressure surface at the center of a ridge is higher than at the outer extent of the ridge. When observing the vertical structure of the atmosphere from the earth's surface to the top of the troposphere (Tropopause), a trough tilts to the north and west (Haltiner and Martin 1957). This allows for divergence aloft associated with the jet stream to be over a surface low-pressure system. Short wave troughs are often indicated by jet

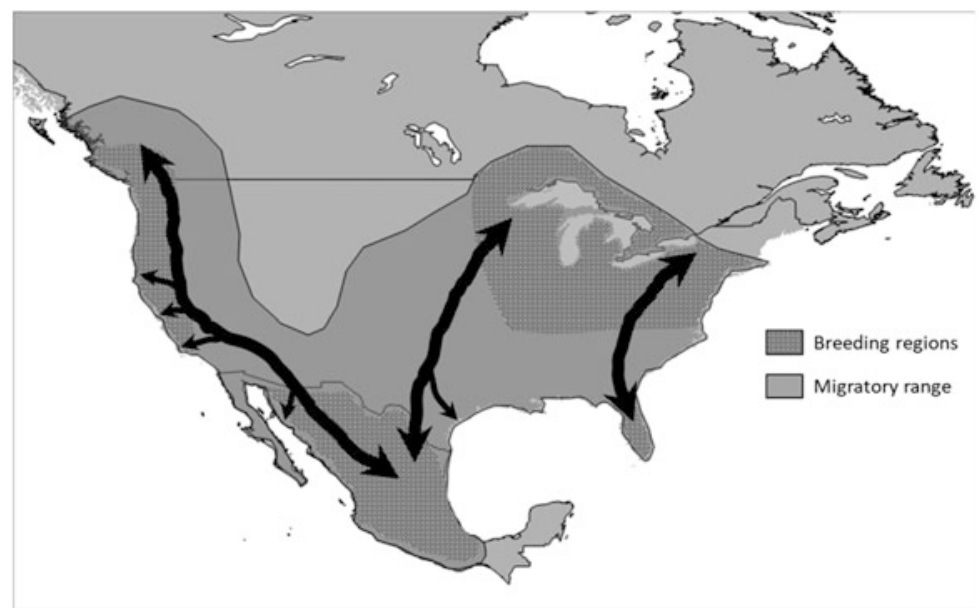

Fig. 2.19 Monarch butterfly migration routes in North America 


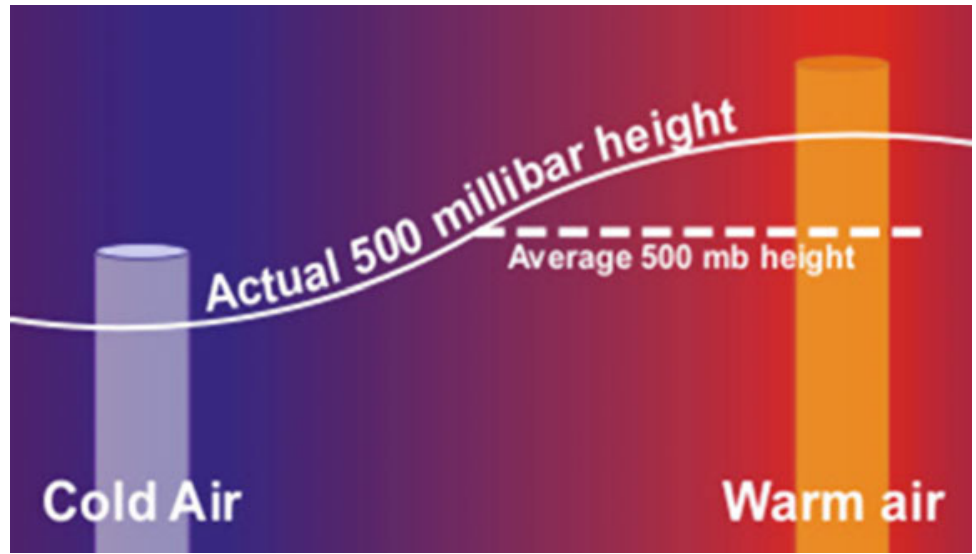

Fig. 2.20 Cross-sectional view of 500-mb height from cold air trough to warm air ridge. http:// www.srh.noaa.gov/jetstream/global/pressure.htm

streaks. Jet streaks (areas of maximum wind) within the jet stream can occur on the upwind side of a trough or at the base or downwind side of a trough. Divergence in the exit region of a jet streak is situated directly over the surface convergence and low-pressure system. Surface lows under an upwind short wave are usually weak because there is little warm air available to promote surface convergence. Jet streaks that occur at the base or upwind side of a trough bring all the ingredients together to form strong surface low-pressure systems.

\subsection{Surface Pressure Systems}

Surface high-pressure systems are located along the leading edge of atmospheric ridges and low-pressure systems are located along the leading edge of atmospheric troughs. When a strong high-pressure system follows a strong low-pressure system, cold air is forced equatorward and warm air poleward. This helps to intensify atmospheric trough and ridge patterns at the $500 \mathrm{mb}$ pressure surface.

The leading edge of cold air is indicated by a cold front and the leading edge of the warm air is indicated by a warm front. Figure 2.21 illustrates the fronts and air masses associated with a strong low-pressure system in the south-central USA. Figure 2.22 is a 3D diagram of the air flow around a low-pressure system. This is a common pattern during late winter to early summer. Frontal systems, as shown on weather maps, are significant catalysts behind the movement of flying animals in the atmosphere. During spring and summer, winds following warm fronts move poleward and are capable of transporting both flying biota such as birds and insects as well as flightless biota. Temperatures reach levels at which flying animals can initiate and sustain flight. For some common moth species, temperatures of $10{ }^{\circ} \mathrm{C}$ $\left(50{ }^{\circ} \mathrm{F}\right)$ are the threshold for flight. At the onset of fall and winter in either 


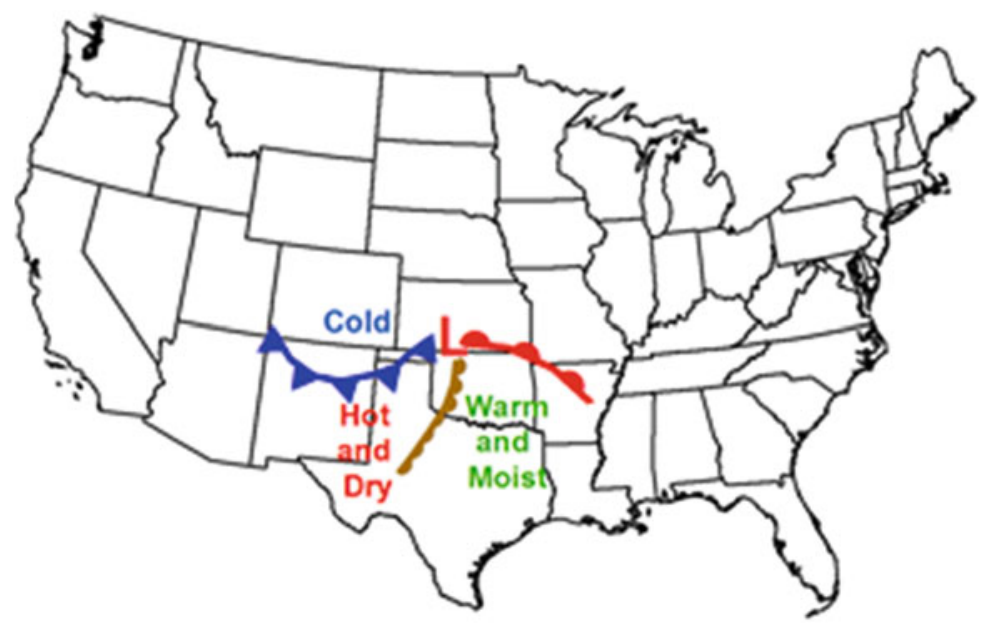

Fig. 2.21 Fronts and air masses associated with a strong low-pressure system in the south-central USA

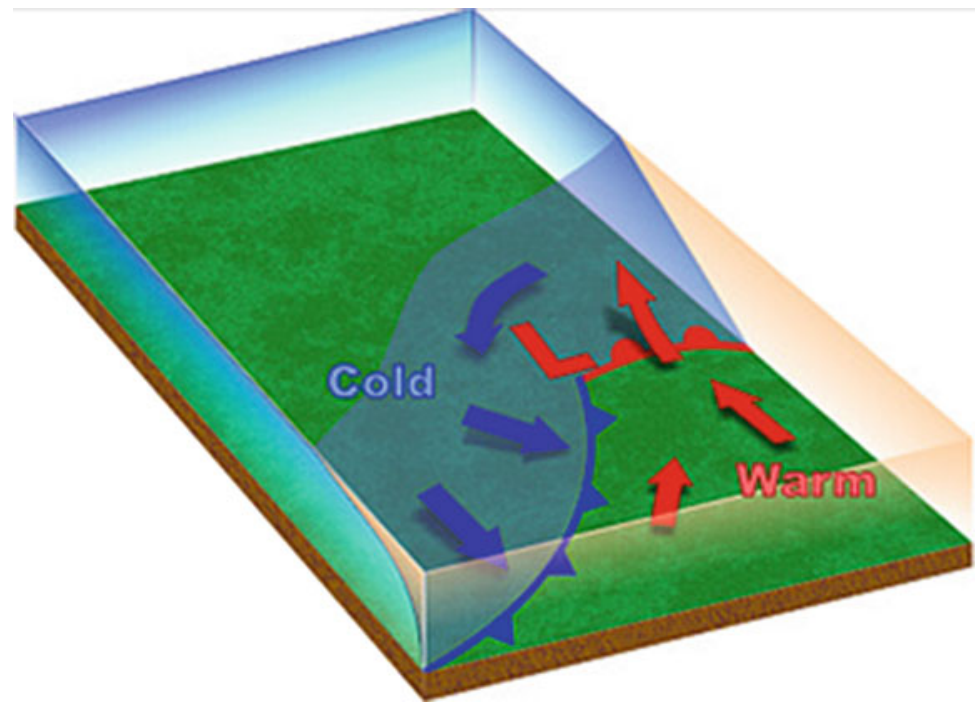

Fig. 2.22 Three-dimensional diagram of the air flow around a low-pressure system. http://www. srh.noaa.gov/srh/jetstream/synoptic/cyclone.htm

hemisphere, flying biota can move toward the equator. Several bird species are known to fly between the Northern and Southern Hemispheres for mating and to return as cold weather develops (Newton 2008). Most long-distance movement occurs in the spring as conditions at the earth surface begin to warm and allow for survival at points further poleward. It is during this time that surface low-pressure 
systems intensify, resulting in strong jet streams aloft and in the atmospheric boundary layer. The presence of low-level jet streams helps to maximize the potential migration displacements of all flying animals poleward where food sources are growing.

\section{$4 \quad$ Mesoscale}

The mesoscale encompasses the atmospheric depth and atmospheric processes that prominently impact migratory flights of animals.

\subsection{Measurement of Thermodynamic and Wind Fields}

We describe atmospheric measurements in the mesoscale section because of predominant flight activity within this atmospheric scale, and the same measurements can also be usefully applied to microscale and macroscale motions. Significant advances in atmospheric profiling instrumentation, widespread deployment of instrumentation, and increased public accessibility to atmospheric data have revolutionized the capability to explore the atmospheric environment and processes that impact the aeroecology of animal species of interest. For many years, the theodolite (a three-dimensional surveying telescope), pilot balloon (pibal), and radiosonde (alternatively named rawinsonde when wind velocity is derived by tracking the balloon) represented the principal equipment used to measure vertical profiles of barometric pressure, air temperature, relative humidity, wind speed, and wind direction. When the theodolite is used to track a pibal without an attached radiosonde, a profile of wind velocity can be computed based on a constant ascent rate for a pibal of known buoyancy and size. Detailed atmospheric profiles of the atmospheric boundary layer can be acquired by increasing the sampling rate of the radio receiver monitoring data transmitted by radiosondes. If a rawinsonde is tracked by radar, a vertical profile of the atmosphere is measured to the highest mandatory pressure altitude of $100 \mathrm{hPa}(100 \mathrm{mb})$ (approximately $16 \mathrm{~km} \mathrm{MSL}$ ) (National Oceanic and Atmospheric Administration 1997). Rawinsonde measurements for operational monitoring networks require maximum vertical extent in order to provide atmospheric data for general circulation models. However, aeroecological research measurements using radiosondes generally limit the vertical extent to $<3 \mathrm{~km}$ AGL but significantly increase the vertical resolution. Further, operational rawinsonde measurements are typically scheduled every $12 \mathrm{~h}$ and may not reveal significant evolution of the atmospheric boundary layer such as during the crepuscular periods of dusk and dawn when bats, noctuid insect species, and other animals are flying. The incorporation of global positioning satellite (GPS) into radiosonde systems obviates the need for theodolite or radar tracking of pibals with attached radiosondes.

In lieu of using rawinsondes to measure vertical profiles of wind velocity, remote sensing systems are currently available. For example, wind profilers and Doppler weather radars remotely detect wind velocities and create vertical profiles of wind 
velocity but use different detection and analysis techniques. Radar wind profilers transmit and receive pulsed radio waves in three directions: vertically and at $75^{\circ}$ above ground along the east-west axis and along the north-south axis from which to compute three-dimensional wind velocities (Mitchell et al. 1995). Doppler weather radars transmit pulsed (and polarized) radio waves at a prescribed set of elevation angles and rotate antennas $360^{\circ}$ to obtain radial components (i.e., along the radar beam) of wind velocity (Klazura and Imy 1993). Horizontal wind velocity values can be estimated as the mean of the azimuthal set of radial components of wind velocity. For both wind profilers and Doppler weather radars, the presence of flying animals confounds the measurement of wind velocity, but these remote sensing systems fortuitously measure the combined wind velocity and animal flight velocity (i.e., resultant ground velocity vector).

Kites and tethered blimps have been used as "sky hooks" to position radiosondes at selected heights and to collect series of measurements within a vertical profile. Further, tethered instrumentation platforms may carry aeroecological monitoring equipment such as cameras, ultrasonic radio detectors, and insect collection nets (McCracken et al. 2008; Krauel et al. 2015). A fixed frame of reference of tethered systems supports collection of local time series of data, but the relatively high speed (i.e., resultant ground speed) of flying animals can impose challenges for effective biological measurements of these animals.

Superpressure mylar balloons (e.g., tetrahedral-shaped balloons or tetroons) are neutrally buoyant at a selected altitude (or more accurately constant-density surface) based on the displacement volume and buoyant lift at the surface. Tetroons maintain altitude along an equilibrium atmospheric density surface. Because tetroons drift with the wind, they provide a moving frame of reference of the wind field that approximates the flight trajectory of migrating animals (Westbrook et al. 1995), and which results in minimum speed of flying animals relative to the tetroon. Similar to the leveraged benefit of tethered platforms, tetroons can carry aeroecological monitoring equipment such as cameras and ultrasonic radio detectors. When atmospheric profiling instrumentation is unavailable, publicallyavailable atmospheric data sets (Table 2.2) can be accessed to reveal details about the dynamic atmospheric environment that are relevant to animal flight.

\subsection{Modeling of the Atmosphere and Animal Flight Displacements}

Simulation models (Table 2.3) and forecasts of atmospheric structure and motions have improved significantly with increased computing power. However, inadequate parameterization and modeling of atmospheric processes continue to introduce errors in estimated profiles of temperature, humidity, and wind velocity values, notably in stable atmospheric boundary layers (Holtslag et al. 2013).

Modeling of airborne displacements of flying animals has typically been simulated by trajectory or dispersion analysis. Trajectories describe a locus of points along the path of movement, with displacement from point to point based 


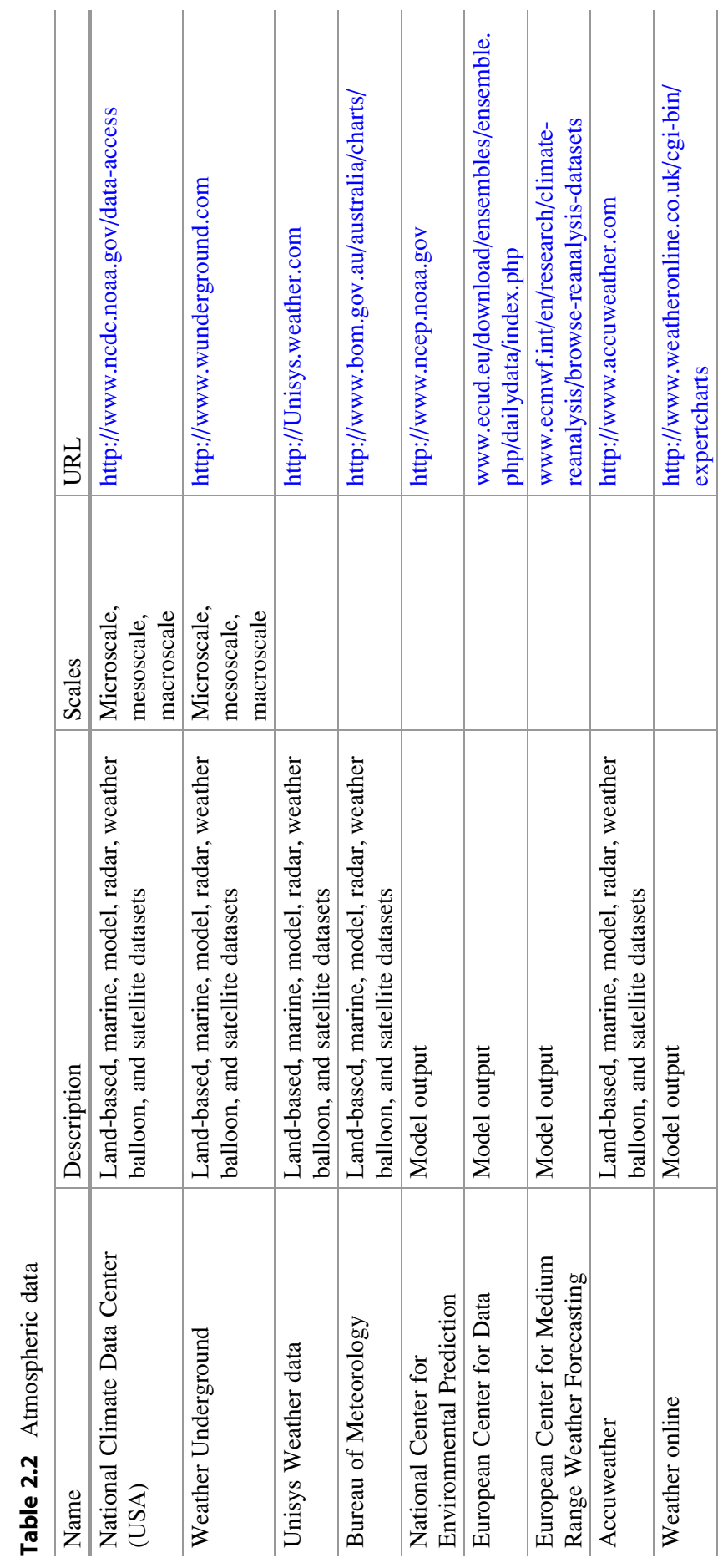




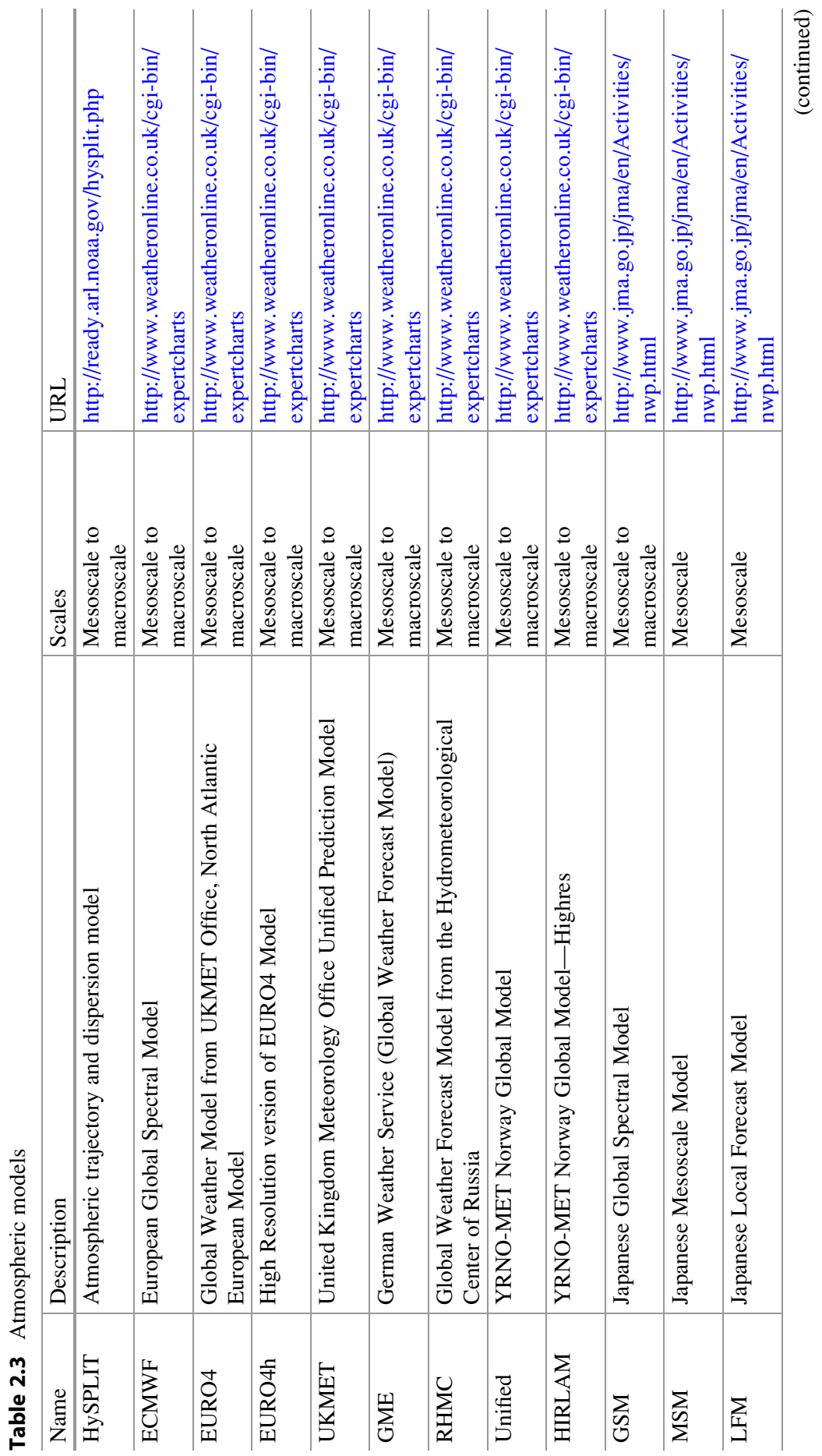




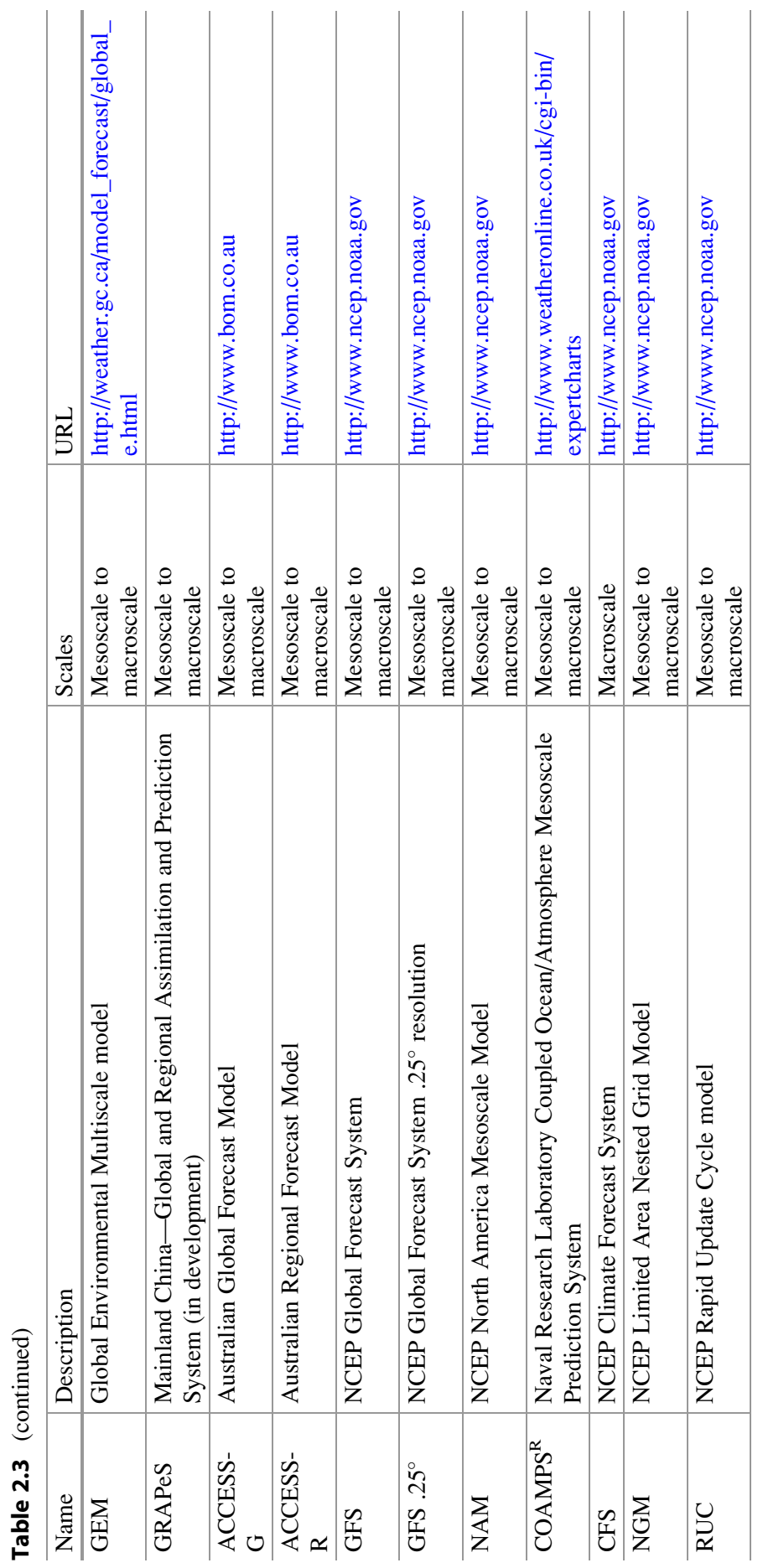


Fig. 2.23 Vector addition of wind velocity and flight velocity

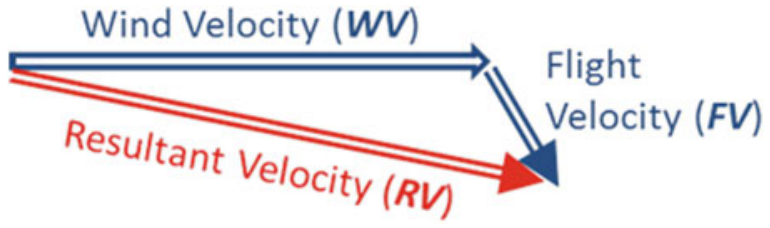

on the speed and direction of movement. Horizontal velocity is a vector that is comprised of magnitude (speed) and direction (relative to north). The horizontal velocity vector can be decomposed into two orthogonal unit vectors, each multiplied by the wind speed component in the respective orthogonal directions (west-to-east and south-to-north). The vector sum of wind velocity ( $W V$ ) and flight velocity $(F V)$ is termed the resultant (or ground-relative) velocity ( $R V$ ) (Fig. 2.23), which is calculated as the sum of the corresponding zonal (westerly) and meridional (southerly) wind velocity components. Trajectories are generally modeled at a specific altitude (Chapman et al. 2010; Westbrook et al. 1997) or atmospheric level (e.g., isobaric or isentropic). Dispersion analysis is similar to trajectory analysis but adds the feature of three-dimensional spread about the trajectory centerline (Westbrook et al. 2011). While trajectory models can estimate the mean path and arrival time of an air parcel or group of migrating animals, dispersion models can also estimate the three-dimensional concentration of migrating animals. Both trajectory and dispersion models generally are used to estimate continuous animal migration. However, trajectory and dispersion models can also estimate discontinuous (e.g., layover stops for flying animals to obtain food, water, and shelter from predators) animal flight. Sufficiently long flight times may lead to trajectories and dispersion patterns that bridge scales of motion.

\subsection{Atmospheric Boundary Layer Temperature Lapse Rates}

The vertical profile of air temperature evolves through the diurnal and nocturnal periods. After sunrise, solar insolation heats the surface which erodes the surface stable layer. During the day, the surface layer heats and mixes through an increasing vertical depth. In the summer, atmospheric mixing can increase the depth of the atmospheric boundary layer to an altitude exceeding $1000 \mathrm{~m}$ above ground level (AGL). However, the presence of subsiding (warming) air within a high-pressure cell suppresses vertical mixing, and creates a subsidence inversion that caps the maximum depth of the daytime atmospheric boundary layer. The temperature profile of the atmosphere is described by the lapse rate, which is defined as the rate of decrease of temperature with height. The standard lapse rate of the troposphere is $6.5^{\circ} \mathrm{C} \mathrm{km}^{-1}$ (American Meteorological Society 2015). We introduce the concept of an adiabatic process in which an air parcel expands (cools) or compresses (warms) as it rises or descends, respectively, with no exchange of heat with the surrounding atmosphere (American Meteorological Society 2015). The dry adiabatic lapse rate $\left(9.8^{\circ} \mathrm{C} \mathrm{km}^{-1}\right)$ applies to the rate of temperature change within unsaturated air parcels that are ascending or descending. After an air parcel 
becomes saturated, vertical motions will change the air parcel temperature at the moist adiabatic lapse rate $\left(5.5^{\circ} \mathrm{C} \mathrm{km}^{-1}\right.$ on average). There are four broad classes of atmospheric stability: highly stable, stable, neutral, and unstable. Various layers within the atmosphere are termed stable if temperature decreases with height at less than the bulk environmental lapse rate, and highly stable if the temperature increases with height (i.e., inversion). Although quite rare, neutral stability occurs when the lapse rate equals the adiabatic lapse rate. Any vertical force on air parcels within a neutral layer will cause air parcels to rise (e.g., from mechanical lifting of air flowing over mountains) or descend (e.g., from downdrafts) without restraint. Unstable atmospheric layers occur when the lapse rate exceeds the adiabatic lapse rate, leading to thermal convection (Haltiner and Martin 1957). Unstable atmospheric layers tend to be transient because vertical convection is induced, which leads to atmospheric mixing and erosion of the unstable lapse rate.

A description of the vertical profile of air temperature and absolute humidity is critical to understanding the current state of the atmosphere. Such a description is presented by the skew-T log-p diagram (Fig. 2.24), which plots the dry-bulb air

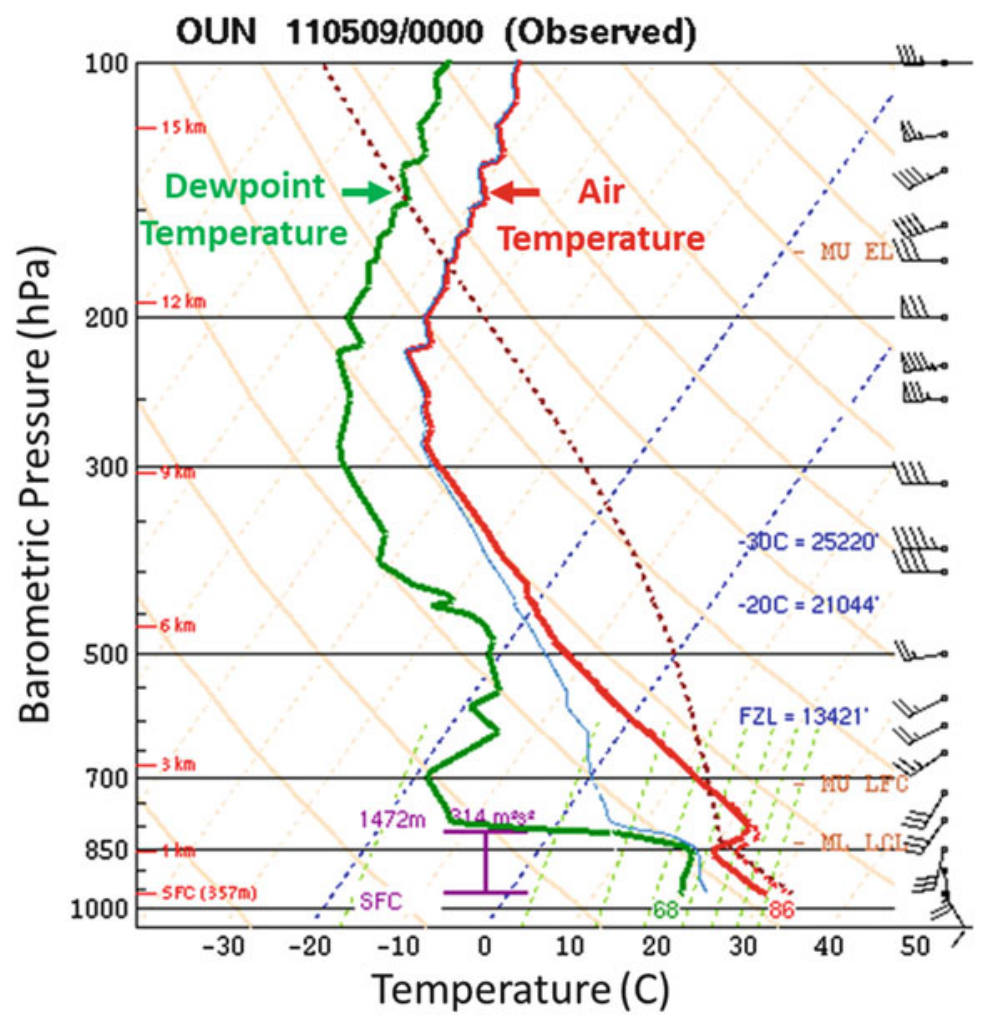

Fig. 2.24 Skew-T diagram depicting vertical profiles of air temperature, dew point temperature, and wind velocity 
temperature and dew point temperature relative to a logarithmic scale of barometric pressure. The skew-T log-p diagram effectively reveals the relative stability or instability of atmospheric layers and identifies the altitude at which convection will result in condensation and cloud formation. Further, wind velocity vectors are plotted along a vertical margin of the skew-T log-p diagram to indicate vertical profiles of wind speed, wind direction, and wind shear. In meteorological convention, wind velocity vectors are identified as arrows pointing in the direction of flow, and for which speed is denoted by the sum value of barbs (i.e., a half-barb $=5$ knots and a full barb $=10$ knots) and pennants (i.e., 50 knots) on the arrow shaft. However, the skew-T log-p diagram is generally based on national networks of rawinsonde observations that measure atmospheric conditions up to and above $100 \mathrm{hPa}(100 \mathrm{mb})$, and additional measurements (e.g., by low-level rawinsondes and wind profilers) are needed to detail the vertical profile of barometric pressure, air temperature, absolute humidity, and wind velocity within the atmospheric boundary layer.

\subsection{Atmospheric Boundary Layer Wind Velocity Profiles}

Horizontal air temperature gradients create gradients of barometric pressure and air density which, in turn, lead to atmospheric motions. Above a smooth surface, atmospheric motions may be laminar and follow the contour of the surface. However, the earth surface is rough, especially in forest, agricultural, and urban environments. Frictional forces caused by atmospheric motions over rough surfaces will reduce near-surface wind speed and generate turbulence. Frictional effects diminish at increasing altitude and consequently affect both wind speed and wind direction. Wind direction tends to rotate within the vertical profile owing to the reduced frictional effects. This feature of the vertical profile of wind direction is known as the Ekman layer (spiral layer). The rotation of wind direction within the atmospheric boundary layer does not exceed $45^{\circ}$ (Hess 1959). The Ekman spiral is described by wind direction that veers clockwise as altitude increases in the Northern Hemisphere and counterclockwise in the Southern Hemisphere. The rotation of wind velocity within the atmospheric boundary layer can be displayed as a hodograph by mapping wind velocity vectors from a common origin (Fig. 2.25). The absence of frictional force at the top of the Ekman spiral results in the attainment of a wind velocity vector (known as the geostrophic wind vector) for which the Coriolis acceleration balances the horizontal pressure force, and the wind flows along the contour lines of an isobaric surface at a speed that is directly proportional to the contour gradient (American Meteorological Society 2015).

In addition to thermally induced changes in the depth and wind velocity profile in the atmospheric boundary layer, overlaying of air parcels from diverse sources (e.g., maritime or continental) can create or enhance the strength of temperature inversions and vertical shear (i.e., speed and/or direction) of the wind velocity profile. 


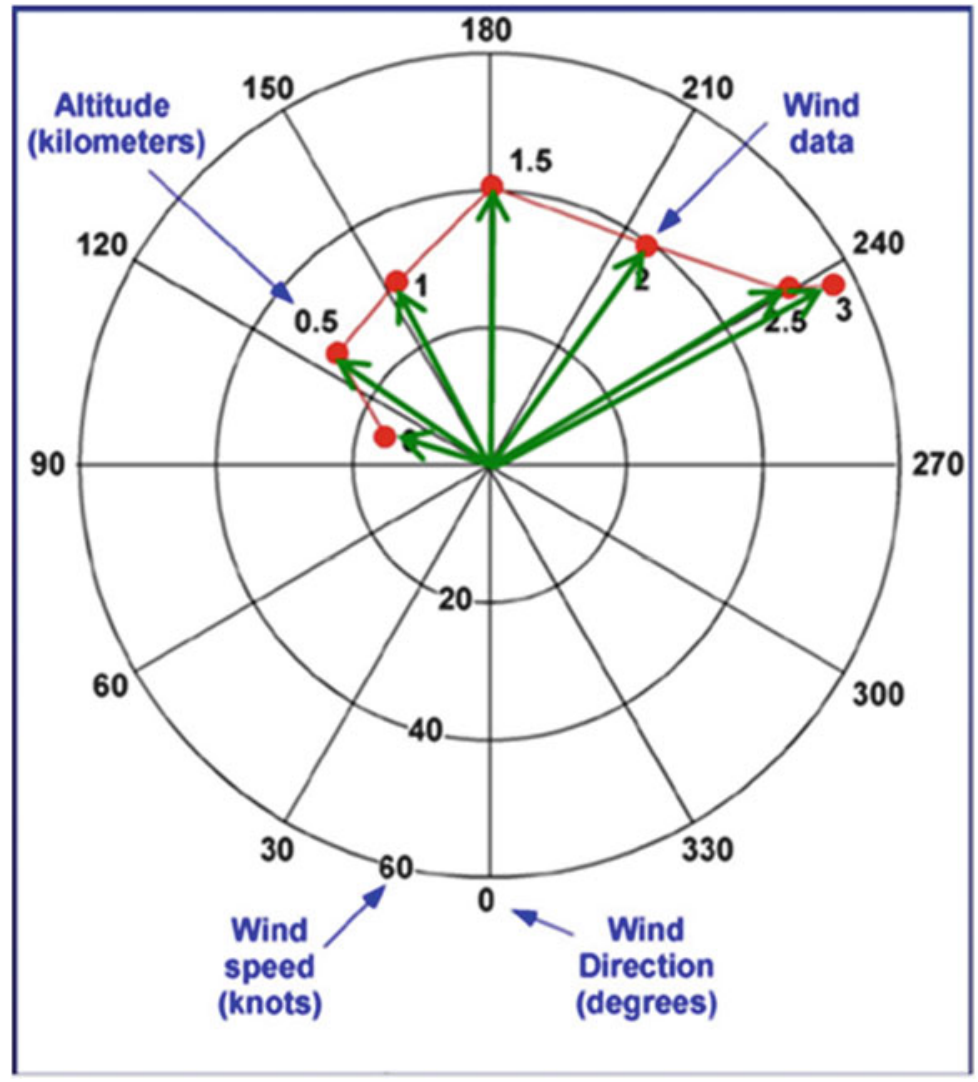

Fig. 2.25 Hodograph illustrating wind shear within the atmospheric boundary layer. http://www. crh.noaa.gov/Image/lmk/Hodographs_Wind-Shear.pdf

\subsection{Episodic Atmospheric Boundary Layer Wind Features}

Macroscale flow above the atmospheric boundary layer is not affected by surface friction. After sunset, a low-altitude temperature inversion often develops between approximately 200 and $600 \mathrm{~m}$ AGL that reduces vertical mixing. Immediately above the low-altitude temperature inversion, the wind speed accelerates as frictional effects are suppressed. The wind maximum in the atmospheric boundary layer is alternatively referred to as the low-level wind jet, as the low-level jet (LLJ), and frequently as the low-level nocturnal jet (Bonner 1968). Low-level jets frequently occur at many geographic locations and are named to identify these specific circulations. Migration of many animal species has been associated with the Great Plains LLJ in the central USA, which often extends for $3000 \mathrm{~km}$ from southern Texas to northern Minnesota. The Caribbean LLJ (Muñoz et al. 2008), South American LLJ (Vera et al. 2006), Somali LLJ (Ardanuy 1979), and many other LLJ are distributed globally (Stensrud 1996). 
Cold air descending from the top of thunderstorms is known as thunderstorm outflow, which can create gust fronts that propagate away from the thunderstorm. Gust fronts are often identified by a narrow band of clouds that can be detected by satellite and radar. Atmospheric convergence along the gust front can concentrate flying animals as the gust front moves for tens or hundreds of kilometers. Flying animals that are caught in the gust front circulation may be unable to escape the gust front before it dissipates.

A phenomenon known as a dry line generates effects similar to those of thunderstorm outflow (Geerts 2008). The dry line boundary separates moist and dry air masses In the USA, the dry line typically orients from south to north during the spring and early summer, where it separates moist air from the Gulf of Mexico (to the east) and dry desert air from the southwestern states (to the west). The dry line typically moves eastward during the afternoon and returns westward at night. A typical dry line passage results in a sharp drop in humidity, clearing skies, and a wind shift from southerly or southeasterly to westerly or southwesterly. Rising temperatures also may follow, especially if the dry line passes during the daytime. These changes occur in reverse order when the dry line retreats westward. Severe and sometimes tornadic thunderstorms often develop along a dry line or in the moist air just to the east of it, especially when it begins moving eastward.

\subsection{Geographically-Fixed Boundary Layer Flows}

Regions with high contrast in surface heat capacity and topographic features develop distinct atmospheric circulations that occur repeatedly and are often defined as a quasi-stationary phenomenon. Contrasts in heat capacity of land and water surfaces often lead to the development of land-sea breeze or land-lake breeze circulations. Diurnal insolation and heating of land generates thermal convection which lowers the surface barometric pressure. Cool air from above the water surface displaces toward the surface low pressure over land. The rising warm air over land spreads laterally and descends over water to close the sea-breeze circulation. Differential nocturnal cooling reverses the circulation and forces a surface land breeze with return flow aloft.

Mountainous regions profoundly influence atmospheric circulations within the atmospheric boundary layer and mixing with the macroscale atmospheric circulation aloft. Greater cooling of mountain slopes can generate substantial horizontal gradients of air temperature and horizontal barometric pressure gradients that lead to a mountain breeze of cool downslope (katabatic) wind (Fig. 2.26). For example, as surface air along the mountain slopes cools by nocturnal radiative heat transfer or by contact with snow and ice, air becomes more dense and descends within a shallow layer along the mountain slope. Conversely, (anabatic) air flow rises as a valley breeze along mountain slopes when heated by insolation or contact with a relatively warm surface (Fig. 2.26). The warm surface air along the slope ascends as thermals, causing a horizontal pressure gradient from the valley toward the mountain slopes. The pressure gradient forces air up the mountainous slope. The speed of 


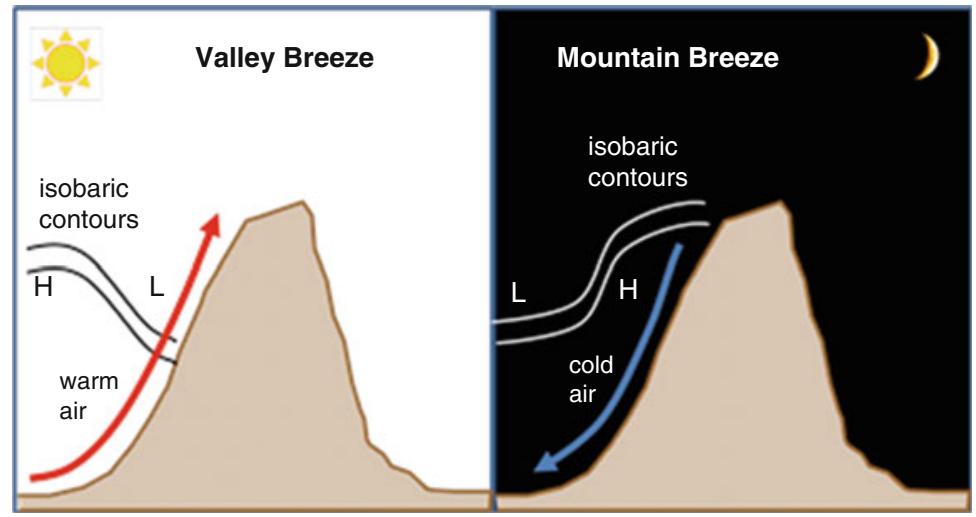

Fig. 2.26 Vertical cross-section of valley- and mountain-breeze circulations

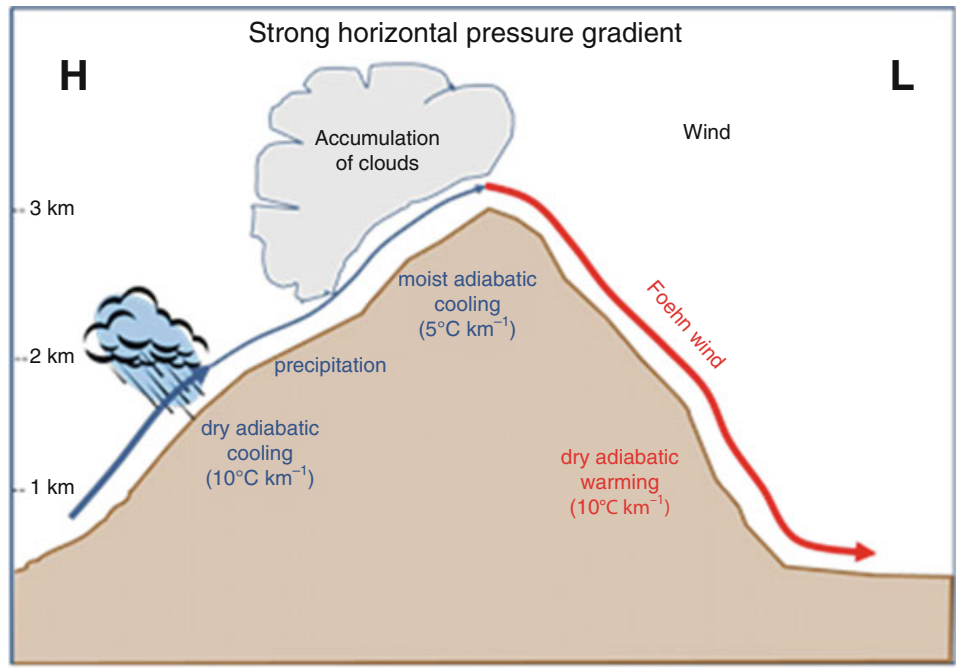

Fig. 2.27 Diagram of foehn wind process

anabatic wind is often less $\left(3-5 \mathrm{~m} \mathrm{~s}^{-1}\right)$ than that of katabatic wind and extends farther above the slope due to convective mixing. When a mountain valley is capped by a stable atmospheric layer, a mountain-valley air circulation rotor may develop in which cross-valley wind at the surface reverses direction aloft similar to that of land-sea breeze circulations. However, if the upper-level atmospheric circulation aligns with the longitudinal axis of the mountain valley and the atmospheric stability within the valley decreases, the mountain-valley rotor will dissipate and surface wind will flow along the longitudinal axis of the valley.

Foehn winds are warm, dry downslope winds that develop when a strong macroscale gradient of barometric pressure forces air flow over a mountain range. Examples of foehn wind (Fig. 2.27) are those in the Alps Mountains of central 
Europe, as well as the Santa Ana wind in the Sierra Nevada mountains of southern California (USA), and the chinook wind in the Rocky Mountains of the USA and Canada. Foehn winds can accelerate to high speeds and rapidly warm the air and can rapidly sublimate snow, evaporate water, and dessicate plant material.

\section{$5 \quad$ Microscale}

The microscale atmospheric environment is typically confined to the surface boundary layer of the atmosphere where surface friction and thermal effects dominate, but microscale atmospheric features are also important between distinct atmospheric layers such as at the top of the convective atmospheric boundary layer where layers of small insects may be concentrated (Eaton et al. 1995). Microscale measurements are commonly acquired by automated meteorological stations on the ground or instrumented towers, by instrumented neutrally buoyant balloons, or by instrumented aircraft, all of which can record air temperature, absolute humidity, barometric pressure, and three-dimensional wind velocity at a fast sampling rate $\left(<1 \mathrm{~s}^{-1}\right)$.

Heat transfer between the earth surface and the surface boundary layer occurs via radiative and conductive processes. During daytime, solar insolation heats the surface according to the solar angle, cloud cover, surface albedo, and surface heat capacity. During nighttime, the cloud cover and surface heat capacity modify the rate of surface cooling. These factors lead to nonuniform heating and cooling of the surface.

Heterogeneous thermal distributions of the surface create air density gradients that induce vertical and horizontal atmospheric motions. The surface lapse rate varies widely during the day and night. A strong (unstable) temperature lapse rate often develops during the day, and strong temperature inversions develop under clear skies at night. During daytime, land surfaces warm quickly causing rising motions (thermals), but water surfaces warm much slower. Conversely, land surfaces cool quickly causing descending motions, and water surfaces remain at nearly constant temperature. Another aspect of the transient nature of the heterogeneous heating and cooling is the development of variable wind speed (i.e., gusts) and direction.

Thermal properties of the surface and thermodynamic processes within the mixed layer cause microscale motions that lead to atmospheric mixing. The mixing generates turbulence that cascades from (i.e., erodes) larger eddies to smaller eddies. At the surface, kinetic energy is dissipated through friction. Similar exchange of turbulent kinetic energy occurs at the interface of distinct atmospheric layers. Thermals create convective air columns that may displace downwind and generally persist and regenerate for periods on the order of minutes, providing lift for soaring flight of animals including Monarch butterflies (Gibo and Pallett 1979). 
Disclaimer Mention of trade names or commercial products in this article is solely for the purposes of providing specific information and does not imply recommendation or endorsement by the U.S. Department of Agriculture.

\section{References}

American Meteorological Society (2015) Adiabatic; geostrophic wind; standard atmosphere. Glossary of Meteorology. Available online at http://glossary.ametsoc.org/wiki/"standard atmosphere"

Ardanuy P (1979) On the observed diurnal oscillation of the Somali Jet. Mon Weather Rev 107: $1694-1700$

Bonner WD (1968) Climatology of the low level jet. Mon Weather Rev 96:833-850

Chapman JW, Nesbit RL, Burgin LE, Reynolds DR, Smith AD, Middleton DR, Hill JK (2010) Flight orientation behaviors promote optimal migration trajectories in high-flying insects. Science 327:682-685

Dowling M (2014) Monsoon at www.mrdowling.com. Updated 30 Dec 2014. Web. Downloaded 25 Feb 2015. http://www.mrdowling.com/612-monsoon.html

Drake VA, Gatehouse AG (1995) Insect migration: tracking resources through space and time. Cambridge University Press, Cambridge, 478 pp

Drake VA, Reynolds DR (2012) Radar entomology: observing insect flight and migration. CABI, Oxfordshire, $489 \mathrm{pp}$

Draxler RR, Hess GD (1998) An overview of the HYSPLIT_4 modeling system of trajectories, dispersion, and deposition. Aust Meteorol Mag 47:295-308

Eaton FD, McLaughlin SA, Hines JR (1995) A new frequency-modulated continuous wave radar for studying planetary boundary layer morphology. Radio Sci 30:75-88

Geerts B (2008) Dryline characteristics near Lubbock, Texas, based on radar and West Texas Mesonet data for May 2005 and May 2006. Weather Forecast 23:392-406

Gibo DL, Pallett MJ (1979) Soaring flight of monarch butterflies, Danaus plexippus (Lepidoptera: Danaidae) during the late summer migration in southern Ontario. Can J Zool 57:1393-1401

Haby J (2015) Atmospheric blocking. http://www.Theweatherprediction.com/blocking/: Blocking Pattern Images

Haltiner GJ, Martin FL (1957) Dynamical and physical meteorology. McGraw-Hill Book, New York, 470 pp

Haltiner GJ, Williams RT (1980) Numerical prediction and dynamic meteorology. Wiley, Hoboken, $477 \mathrm{pp}$

Hess SL (1959) Introduction to theoretical meteorology. Holt, Rinehart and Winston, New York, $362 \mathrm{pp}$

Holtslag AAM, Svensson G, Baas P, Basu S, Beare B, Beljaars ACM, Bosveld FC, Cuxart J, Lindvall J, Steeneveld GJ, Tjernström VDWBJH (2013) Stable atmospheric boundary layers and diurnal cycles: challenges for weather and climate models. Bull Am Meteorol Soc 94: 1691-1706

Isard SA, Gage SH (2001) Flow of life in the atmosphere: an airscape approach to understanding invasive organisms. Michigan State University Press, East Lansing, $240 \mathrm{pp}$

Kim KS, Jones GD, Westbrook JK, Sappington TW (2010) Multidisciplinary fingerprints: forensic reconstruction of an insect reinvasion. J R Soc Interface 7:677-686

Klazura GE, Imy DA (1993) A description of the initial set of analysis products available from the NEXRAD WSR-88D system. Bull Am Meteorol Soc 74:1293-1311

Krauel JJ, Westbrook JK, McCracken GF (2015) Weather-driven dynamics in a dual-migrant system: moths and bats. J Anim Ecol 84:604-614

Kunz TH, Gauthreaux SA Jr, Hristov NI, Horn JW, Jones G, Kalko EKV, Larkin RP, McCracken GF, Swartz SM, Srygley RB, Dudley R, Westbrook JK, Wikelski M (2008) Aeroecology: probing and modeling the aerosphere. Integr Comp Biol 48:1-11 
Madden R, Julian P (1971) Detection of a 40-50 day oscillation in the zonal wind in the Tropical Pacific. J Atmos Sci 28:702-708

Madden R, Julian P (1972) Description of global-scale circulation cells in the tropics with a 40-50 day period. J Atmos Sci 29:1109-1123

McCracken GF, Gillam EH, Westbrook JK, Lee Y-F, Jensen ML, Balsley BB (2008) Brazilian free-tailed bats (Tadarida brasiliensis: Molossidae, Chiroptera) at high altitude: links to migratory insect populations. Integr Comp Biol 48:107-118

Mitchell MJ, Arritt RW, Labas K (1995) A climatology of the warm season great plains low-level jet using wind profiler observations. Weather Forecast 10:576-591

Muller RA (1977) Synoptic climatology for environmental baseline analysis: New Orleans. J Appl Meteorol 16:20-33

Muñoz E, Busalacchi AJ, Nigam S, Ruiz-Barradas A (2008) Winter and summer structure of the Caribbean low-level jet. J Clim 21:1260-1276

National Oceanic and Atmospheric Administration (1997) Rawinsonde and Pibal observations. Federal Coordinator for Meteorological Services and Supporting Research, Federal Meteorological Handbook No. 3, FCM-H3-1997, Washington, DC, 191 pp

Pedgley D (1982) Windborne pests and diseases: meteorology of airborne organisms. Ellis Horwood, Chichester, $250 \mathrm{pp}$

Pidwirny M (2006) Local and regional wind systems. Fundamentals of physical geography, 2nd edn. Date Viewed 3/11/2015. Monsoon Southeast Asia. http://www.physicalgeography.net/ fundamentals $/ 7 \mathrm{o} . \mathrm{html}$

Stensrud (1996) Importance of low-level jets to climate: a review. J Clim 9:1698-1711

Vera C, Baez J, Douglas M, Emmanuel CB, Marengo J, Meitin J, Nicolini M, Nogues-Paegle J, Paegle J, Penalba O, Salio P, Saulo C, Silva Dias MA, Silva Dias P, Zipser E (2006) The South American low-level jet experiment. Bull Am Meteorol Soc 87:63-77

Wallace JM, Hobbs PV (1977) Atmospheric science: an introductory survey. Academic Press, New York, $467 \mathrm{pp}$

Westbrook JK, Eyster RS, Wolf WW, Lingren PD, Raulston JR (1995) Migration pathways of corn earworm (Lepidoptera: Noctuidae) indicated by tetroon trajectories. Agric For Meteorol 73:67-87

Westbrook JK, Wolf WW, Lingren PD, Raulston JR, López JD Jr, Matis JH, Eyster RS, Esquivel JF, Schleider PG (1997) Early-season migratory flights of corn earworm (Lepidoptera: Noctuidae). Environ Entomol 6:12-20

Westbrook JK, Isard SA (1999) Atmospheric scales of biotic dispersal. Agric Forest Meteorol 97: 263-274

Westbrook JK (2008) Noctuid migration in Texas within the nocturnal aeroecological boundary layer. Integr Comp Biol 48:99-106

Wolf WW, Westbrook JK, Raulston JR, Pair SD, Lingren PD (1995) Radar observations of orientation of noctuids migrating from corn fields in the Lower Rio Grande Valley. Southwestern Entomol Suppl 18:45-61 